\title{
MONSEÑOR ORREGO Y LOS CONFLICTOS ENTRE CATÓLICOS Y LAICISTAS EN LA SERENA
}

\author{
POR \\ María Macarena CoRdero Fernández \\ Universidad Adolfo Ibáñez \\ maria.cordero@uai.cl
}

\section{RESUMEN}

En los primeros años de la República la base cultural de la sociedad chilena era la tradición católica. Pero, a mediados del siglo XIX las tendencias librepensadoras adquirieron más relevancia social y política, provocando que la elite se cuestionara el rol que la Iglesia debía jugar en la vida pública nacional. En este contexto hacia la modernidad y el liberalismo, en La Serena se produjeron conflictos entre liberales y conservadores manifestándose en tiempos del obispo Orrego, ultramontano que desde su diócesis intentó impedir la secularización de la sociedad.

PALABRAS CLAVES: Laicización o secularización, disputas Iglesia Estado, ultramontanos, liberales, Patronato.

\section{MONSIGNOR ORREGO AND THE CONFLICTS BETWEEN CATHOLICS AND SECULARIST IN LA SERENA}

\begin{abstract}
In the first period of the Republican era, the cultural substrate of Chilean society was based upon catholic tradition. However, in the mid nineteenth century the freethinking tendencies gained further political and social power, causing the questioning of the upper classes whether it was desirable that the Church had so much influence in the public sphere of the nation. In La Serena, at times of modernity and liberalism, conflict emerged between liberals and conservatives, in which bishop Orrego played an important role preventing the expansion of secularization throughout Chilean society.
\end{abstract}

KEY WORDS: Secularization, State/Churche conflicts, ultramontano, liberals, Patronage.

Recibido/Received 11-08-2014

Aceptado/Accepted $\quad 08-10-2014$

Desde mediados de la década de los 40 del siglo XIX, se inició una serie de fricciones entre las tendencias católica y laicista, las que se debieron a profundas razones de índole política e ideológica, que finalmente se volvieron irreconciliables. Los católicos, por un lado, deseaban mantener la unidad espiritual de los chilenos; y por el otro, los gobiernos secularizantes pretendían desligarse públicamente de toda influencia de la Iglesia. Pese a ello, tanto el Gobierno como la Iglesia habían logrado mantener un aparente equilibrio en sus relaciones y aspiraciones. ${ }^{1}$

1 Nos hemos valido del periódico católico La Diócesis, de la ciudad de La Serena, el cual ha sido nuestra principal fuente, revistiendo un gran valor histórico pues da cuenta de la realidad regional. Biblioteca Nacional de Chile (BNCH). Microfilm (Mic.): PCH 1516 y 1517.

Este periódico, creado a fines de 1881 por iniciativa del obispo José Manuel Orrego, ilustra los momentos críticos del conflicto en la ciudad de La Serena. Precisamente, en el transcurso de esos años, el mismo obispo se enfrentó a las tendencias secularizadoras con tenacidad y arrojo.
Sin embargo, a finales del siglo XIX ambos sectores, frente a los cambios culturales, se fueron radicalizando

Lamentablemente, no se dispone de todas las ediciones del periódico La Diócesis, porque dicho material está destruido, ajado o simplemente incompleto, lo que plantea un desafío metodológico a la hora de interpretar los acontecimientos. Simultáneamente con la revisión de este material, que forma el trasfondo de esta investigación, hemos consultado una serie de registros que dan cuenta de los acontecimientos a nivel nacional, pero necesarios para comprender el contexto en que se desarrolla la disputa en la diócesis de La Serena, provincia norteña en aquel entonces de Chile. Entre ellos, la correspondencia personal de Domingo Santa María con el representante chileno en Roma Alberto Blest Gana, publicada en la colección de fuentes "De Taforó a Casanova"; asimismo, una serie de biografías y relatos de la época en la que se transcriben correspondencia privada y pareceres de los protagonistas, tales como Rodolfo Vergara, Crescente Errázuriz, Abdón Cifuentes, entre otros. Algunos legajos del archivo del Ministerio de Relaciones Exteriores, mediante los cuales es posible acercarnos a los sucesos; revisamos también el Boletín Eclesiástico; diversas cartas pastorales del obispo Orrego, y la biografía del prelado elaborada por su contemporáneo y subalterno, Juan Ramón Ramírez. 
ideológica y políticamente hasta llegar al punto de que ninguno estuvo dispuesto a transigir. Tanto la Iglesia como el gobierno defendían en los espacios públicos nacionales, ${ }^{2}$ las prerrogativas y privilegios inherentes a su poder, con la pretensión de influir en la opinión pública. ${ }^{3}$

Esta disputa entre laicistas y católicos se escenificó también en la diócesis de La Serena, y se manifestó en incidentes y roces que tensaron aún más las relaciones entre las autoridades gubernamentales y las eclesiásticas.

A fines de 1882 el obispo de la Serena, José Manuel Orrego, estaba en las vísperas de un viaje a Europa. Inesperadamente, el ministro del Culto, Eugenio Vergara, le comunicó que no podía salir del país, pues no contaba con la «licencia o autorización» del gobierno. Ante ello, el prelado protestó enfáticamente, respaldado por el clero y los innumerables fieles de la ciudad.

Con este episodio comenzó una áspera y a veces violenta disputa entre liberales y católicos, cuyo trasfondo era en realidad, la búsqueda de la primacía cultural frente a los adversarios.

En efecto, durante los primeros años de la República la base cultural de la sociedad chilena era la tradición católica. Sin embargo, a partir de 1840 las tendencias librepensadoras adquirieron cada vez más relevancia social y política, que se manifestaron

...en luchas por independizar a los ciudadanos de la tutela religiosa en materias como el matrimonio, los nacimientos, los cementerios y la educación. Surgió un poderoso anticlericalismo que no necesariamente tenía un carácter antirreligioso (la gran mayoría siguió siendo católica), sino más bien buscaba terminar con los privilegios eclesiásticos a través de los cuales la Iglesia ejercía poder sobre la gente común. ${ }^{4}$

El ideario del partido liberal y radical abogaban en dicha dirección. Ante ello, el catolicismo debió comprender que aumentaba el número de personas que no se identificaban con su fe. ${ }^{5}$

La organización de la República, las formas constitucionales y las políticas económicas eran entonces temas que suscitaban consenso en los diversos sectores políticos del país. Sin embargo, el papel que debía jugar la Iglesia Católica

2 Entendemos por «Espacio Público» como aquel en el que el debate y la crítica se producen de forma libre. De ahí que sea condición que esta esfera se encuentre sustraída de la influencia del poder público, pues también tiene como objetivo debatir sobre ella. Vid. Habermas Jurgen. 1991. Historia y crítica de la opinión pública. La transformación estructural de la vida pública. Barcelona: Chartier Roger. 2003. Espacio público, crítica y desacralización en el siglo XVIII. Los orígenes culturales de la Revolución Francesa: 29. Barcelona: Gedisa.

3 La opinión pública se refiere a la comunidad crítica de una sociedad, que está conformada por «todas las personas privadas que, en su carácter de lectores, oyentes y espectadores -siendo supuesta su posesión de bienes y cultura- estaban en condiciones de dominar el mercado de los temas en discusión». Habermas Jurgen. 1986. L' espace public: archéologie de la publicité comme dimensión constitutive de la societé bourgeoise: 49. Paris: Payot.

4 Larraín, Jorge. 2005. ¿América Latina Moderna? Globalización e identidad: 42. Santiago: LOM Ediciones.

5 Krebs, Ricardo. 1981. “La Iglesia y el mundo moderno", en Ricardo Krebs (dir.), El pensamiento de la Iglesia frente a la laicización del Estado de Chile 1875-1885: 9. Santiago: Nueva Universitaria. en la vida pública nacional era un asunto que provocaba controversia. En tal sentido, Alberto Edwards afirmaba:

...se trata, sin duda, de un solo movimiento espiritual que, aunque lo consideremos negativo, en su esencia es de índole religiosa. El alma colectiva de la sociedad se ha ido transformando o demoliendo; las reformas políticas o sociales no son sino efectos de esa honda revolución moral. ${ }^{6}$

El creciente avance del poder laico frente a la Iglesia hizo temer a los católicos por el futuro de la sociedad chilena, toda vez que se perdía -a su juicio- la unidad religiosa, base de la unidad nacional. De esta manera, la crisis de la época moderna, la rebelión del alma social contra las antiguas fuerzas espirituales de la cultura, también iniciaba su eclosión en Chile. ${ }^{7}$ Más aún, los liberales consideraban que "La independencia política no era suficiente; también era necesario cambiar viejos hábitos de pensamiento, renovar costumbres, abandonar actitudes coloniales». ${ }^{8}$ En suma, emancipar el espíritu y las mentes, «despañolizar», ${ }^{9}$ y descatolizar Chile. ${ }^{10}$

Frente al arrollador tránsito de la modernidad y sus ideas liberalizadoras, la Iglesia se vio obligada a organizarse para combatir el "error religioso de los liberales». La religión debía ser la norma y base para el Estado, sociedad y cultura; y el catolicismo, el elemento esencial de la unidad nacional.

\section{ANTECEDENTES DE LA DISPUTA}

\section{Catolicismo versus Liberalismo, y la postura de Orrego}

El pensamiento cambió a pasos agigantados durante el siglo XIX en el mundo occidental, y también en Chile. Se configuró una nueva realidad social y política en los pueblos debido a la difusión del liberalismo y otras corrientes intelectuales modernas. Comenzaron a circular diarios y periódicos de corte liberal, en los cuales se ridiculizaba la religión y se aspiraba a reformar la sociedad.

El liberalismo en Chile, donde presentó características propias, pero influenciado por el pensamiento europeo, tenía como propósito regenerar la sociedad: «...desespañolizarse y recuperar la naturaleza humana trastornada por la conquista». ${ }^{11}$

6 Edwards, Alberto. 2001. La Fronda Aristocrática: 138. Santiago: Universitaria.

7 Ibídem: 120 y ss.

8 Larraín, Jorge. 2005: 42.

9 El concepto de «despañolización» se ha interpretado desde la perspectiva ilustrada y moderna de los intelectuales liberales chilenos de mediados del siglo XIX. Esto es, el proceso de ruptura con el sistema colonial en su totalidad.

10 Bilbao Francisco. 1995. "Iniciativa de la América. Idea de un Congreso Federal de la República", en Leopoldo Zea (coord.), Fuentes de la Cultura Latinoamericana: 58, Tomo I. México: Tierra Firme.

11 Es más, "Algunos postulados europeos de los siglos XVII y XVIII, que constituyen el sustrato ideológico en que fermenta el liberalismo político del siglo XIX, como la fe en la educación, el relativismo históricocreencia de que debía reformar al hombre reformando la conciencia-, y los principios de la igualdad ante la ley y de libertad de pensamiento, ejercieron en Chile, ya en el momento de la Independencia, una gran atracción...». Subercaseaux Bernardo. 1997. Historia de las ideas y de la cultura en Chile: 17, Vol. I. Santiago: Universitaria. 
Y claro está que en este proceso de desespañolización, que algunos vieron como necesario, se buscaba eliminar las viejas costumbres e instituciones coloniales, entre ellas la Iglesia. Para ello era necesario primero reformar la conciencia para luego transformar la realidad. Es decir, la conciencia debía emanciparse del peso cultural que caía sobre ella hasta entonces. De esta forma, se iniciaría el viaje a la modernización de las instituciones, que a ojos de los liberales equivalía a progresar.

Para fundar esta nueva nación, se hizo forzoso que existiera un recambio en el ámbito artístico y cultural, pues con las ideas se renovaba la sociedad. Surgieron figuras como Bilbao y Lastarria, que influyeron sobre los hermanos Amunátegui, Barros Arana, Vicuña Mackenna, intelectuales y políticos que combatieron en pro de los derechos del Estado y en contra de la influencia de la Iglesia. A su vez, estos liberales regalistas abrieron los fuegos de la batalla por la libertad de culto, la secularización y la libertad de conciencia. ${ }^{12}$

Los más radicales consideraron a la Iglesia como parte del Antiguo Régimen, identificándola con conceptos como oscurantismo o despotismo. Por tanto, era necesario luchar contra el clero y lograr la libertad de las conciencias, pues la religión era un asunto propio de este espacio íntimo. Respecto de la Iglesia, estimaban que debía ser separada del Estado, quedar al margen de la vida pública y sujeta al derecho nacional, como cualquier otra asociación. Dicho de otro modo, las nuevas tendencias creían que era necesario eliminar todas las influencias de la Iglesia sobre la sociedad, convirtiendo al Estado en la única autoridad suprema capaz de guiar al hombre.

La máxima del progreso indefinido de la humanidad, amén de la razón, la ciencia y los nuevos descubrimientos que conducirían al hombre a un estado cada vez más perfecto, empapaban el ideario de los liberales chilenos. Tales ideas eran compartidas, asimismo, por el Presidente Santa María, tal vez el más tenaz reformista de los gobernantes que se sucedieron a finales del siglo XIX..$^{13}$

Para los católicos, el liberalismo, principal enemigo que surgió en el siglo, fue calificado como un error religioso,

El concepto de moderno que se ha utilizado, corresponde a la idea de que la sociedad deja de estar regida por el pasado, de la forma en que se hicieron siempre las cosas, y se abre radicalmente a un futuro incierto y por construir. Larraín Jorge. 2005: 11. Con todo, debemos tener presente que la apropiación de la modernidad sólo se hizo presente en Chile luego de tres siglos de regirse por un sistema simbólico dado por la estructura colonial. De ahí, luego de la Independencia, las elites resignificaron y reinterpretaron el concepto en cuestión conforme a su propia cultura barroca, y originaron una especie de modernidad hispanoamericana, con rasgos propios y desarrollada en etapas y procesos diversos a los europeos.

12 Los intelectuales liberales chilenos de mediados del siglo XIX estaban insertos en la corriente ilustrada, cuestión que significaba considerar que el hombre era libre de utilizar su propio entendimiento. Dicho de otro modo, cada uno debe pensar por sí mismo y romper con los idearios obligados y herederos. Para ello es necesario contar con espacios públicos, donde se pueda debatir y realizar críticas, sustraídos de la influencia del poder público.

13 Para detalles del ideario de Santa María, vid. Encina Francisco. 1983-1984. Historia de Chile: Tomo XXXIV. Santiago; Walker Martínez Carlos. 1886. La Administración de don Domingo Santa María. Epílogo. El hombre muerto. Santiago: La Libertad Electoral. puesto que contenía una doctrina política y económica fundada en una concepción antropocéntrica del mundo y de la existencia, que proclamaba que los hombres eran libres, iguales y autónomos, lo que conllevaba que la ley divina dejara de ser una norma reconocida socialmente. ${ }^{14}$

Si bien es cierto que durante cientos de años se habían producido persecuciones a la Iglesia originadas en diversas tendencias religiosas, los ataques ocurridos en el siglo XIX eran de índole distinta, pues a juicio de monseñor Orrego, consistían en la negación de Cristo, y por ende de la civilización cristiana. ${ }^{15}$ Además, el liberalismo apuntaba a favorecer la secularización de la vida social, el naturalismo religioso y el ateísmo, pretendiéndose llevar al hombre a:

...desconocer la religión, lo cual hará... que viva en el ateísmo histórico y sea prisionero del ateísmo práctico... en el orden moral la secularización anulará... la influencia de la Iglesia a fin de que avance el paganismo... Y en el orden social la secularización arrancará a la autoridad un carácter divino y dejará al hombre en presencia de hombre; al hombre déspota frente al hombre esclavo... ${ }^{16}$

Una situación como ésta era inaceptable. Es más, para los serenenses católicos, la secularización no era más que «...una protesta y una insurrección salvaje contra el dominio de la Iglesia, a quien el mundo entero debe los beneficios de la civilización...». ${ }^{17}$

A su vez, los conservadores católicos pensaban que el liberalismo relativizaba absolutamente toda verdad o principio, so pretexto de la tolerancia. Con ello sacaba de la esfera moral y de la educación a la religión y, de paso, producía el divorcio entre fe y razón, lo que conduciría irremediablemente a la sociedad al materialismo. ${ }^{18}$

Progresivamente, la élite chilena fue entrando al campo del debate sobre la relación Estado-Iglesia, centrándose en la cuestión de los cementerios y el matrimonio, la secularización de la enseñanza y la separación Estado-Iglesia, pues ésta era vista como instrumento de las fuerzas retrógradas. En otras palabras, se abría un abismo entre la Iglesia y el mundo moderno racionalista que ponía en peligro las bases sobre las cuales descansaba la sociedad y el Estado hasta ese entonces.

La Iglesia demostraba abiertamente que no deseaba transar con el mundo secularizado, pero que no estaba dispuesta a perder su influencia cultural. La religión católica era -y debía seguir siendo- la fuerza espiritual dominante en las conciencias y en las costumbres; de lo contrario, el secularismo provocaría la corrupción moral, la desorganización, el caos y la anarquía. «El liberalismo no quiere la Iglesia libre en el Estado libre, sino una Iglesia esclava del Estado.

14 "Editorial del 2 de abril de 1882". La Diócesis 2. Ver también ediciones del 2 de diciembre de 1875, 29 de abril de 1876, № 489, 4 de enero de 1879, № 876, 16 de enero de 1879, № 88, 1 de febrero de 1879, entre otras, del periódico El Correo de la Serena.

15 1883. "Carta pastoral de Orrego dirigida a sus fieles serenenses". La Diócesis 45.

16 1883. La Diócesis 70.

17 1883. La Diócesis 68.

18 1883. "Carta pastoral de Orrego a sus fieles, publicada el 24 de febrero". La Diócesis 45. 
Si llegasen a cumplir ese objetivo, se produciría el desorden en la sociedad hasta llegar a la barbarie». ${ }^{19}$

Aun más, los católicos chilenos estimaban que la República se había construido gracias a la religión católica. Ello implicaba considerar que la unidad confesional asentaba la unidad territorial, social y política de Chile. De perderse la unidad religiosa, se producirían enfrentamientos entre grupos nacionales y el decaimiento de los valores, provocando que los poderes político y jurídico se desprendieran de la moral cristiana.

Con todo, los católicos no se desanimaron. Creían en el triunfo, pues la historia de la Iglesia estaba llena de ejemplos donde el cristianismo había salido victorioso de los distintos embates.

La postura de monseñor Orrego, de los fieles y sacerdotes de la diócesis de La Serena, frente a la corriente liberal exacerbada que se presentó a finales del siglo, se caracterizó por una firme oposición a la marea laicista, al llamado «espíritu del siglo». Sumado a lo anterior, el ideario de Orrego fue siempre contrario al Derecho de Patronato y demás regalías, lo que generó aún más resistencia de los gobernantes de turno.

Cabe preguntarnos entonces en qué consistían aquellos derechos.

\section{El Derecho de Patronato y el Regalismo}

Como hemos visto, a finales del siglo un sector de la élite chilena era de tendencia liberal. Por ello inició una campaña contra la Iglesia que mermara su trascendencia en la vida nacional y limitara su campo de acción, para, de este modo, poder contrarrestar su influencia en las conciencias.

A su vez, ya en aquel entonces se deseaba, por algunos, una separación completa de la Iglesia y el Estado, la secularización de toda la vida nacional y sus instituciones. ${ }^{20}$

No obstante, se produjo una dualidad en los grupos combatientes. Por un lado, los liberales chilenos deseaban que la Iglesia se mantuviera ajena a toda influencia pública, y reclamaban, al mismo tiempo, una serie de derechos que creían le correspondían al Estado. Por otro lado, la Iglesia luchaba por su libertad y por conservar su influencia en la vida nacional; pero, asimismo, quería seguir gozando de una serie de privilegios que el Estado le reconocía, entre ellos ser su religión oficial con exclusión del ejercicio público de todo otro culto. ${ }^{21}$

Evidentemente, las posiciones eran irreconciliables, lo que constituye un antecedente de vital importancia para poder entender el período y las largas disputas entre los bandos enemigos. Necesario es, entonces, conocer qué derechos reclamaba como suyos el gobierno chileno, a los que el clero batallador opuso tenaz resistencia.

19 1883. La Diócesis 70.

20 Al respecto, durante el gobierno de Domingo Santa María contempló un proyecto de separación de la Iglesia y el Estado. Para más detalles, ver Encina, Francisco. 1983-1984: 131 y ss.

${ }^{21}$ En este punto se ha seguido a Encina, Francisco. 1983-1984: Tomo XXIX, 85.
Desde los inicios de la República, el gobierno chileno había reclamado como suyas las facultades que otorgaba el regalismo y aducía que era sucesor de los derechos de los reyes de España. ${ }^{22}$ Sin embargo, la Santa Sede no concedió jamás tales prerrogativas a Chile. ${ }^{23}$

El Patronato y demás regalías implicaban, entre otras cosas, el exequátur, que exigía del Consejo de Indias el permiso necesario para que se despacharan a América las órdenes y documentos pontificios; el recurso de fuerza, que autorizaba a los sacerdotes a recurrir a la justicia ordinaria de fallos y órdenes de la autoridad eclesiástica, y la prerrogativa del Presidente de la República de presentar candidatos a arzobispos y obispos. ${ }^{24}$

Pues bien, la Constitución de 1833 había establecido en su artículo 5ㅇqu la religión de la República era la Católica, Romana y Apostólica, con exclusión del ejercicio de cualquier otra. Consagró también el sistema del Patronato, lo que fue posible porque el clero chileno era regalista al iniciarse la República. Por lo demás, el regalismo implicaba un contrapeso de deberes del Estado; esto es, protección, privilegios y garantía al catolicismo de ser la única religión oficial del País.

Sin embargo, el mundo de las ideas había entrado en una etapa de cambio veloz, y la religión estaba en riesgo. Ante ello, la Iglesia inició un proceso donde revisó su doctrina, y así el clero chileno pasó de tener una postura regalista a

22 Sobre el derecho de patronato, es necesario recordar brevemente que España al conquistar las Indias tenía entre muchas misiones la de evangelizar, por encargo expreso del Papa Alejandro VI en la bula "Inter Caetera" de 1493. Para facilitar dicha tarea, la Santa Sede concedió a los reyes de España el Derecho de Patronato sobre la Iglesia en América, por medio del cual se otorgaba a los monarcas la facultad de presentar al Papa los candidatos para ocupar los cargos de arzobispo, obispo y canónicos de las catedrales. Asimismo, se les autorizó a cobrar la contribución eclesiástica del diezmo y a retener una parte del mismo.

Pero la Corona, sobre todo en tiempos de los Borbones, se atribuyó otras facultades en razón del regalismo.

El regalismo dice relación con la pretensión de los monarcas de contar con derechos privativos, esto es, una serie de privilegios o regalías que cubrían diversos ámbitos, entre ellos los eclesiásticos, a base de que éstos derechos eran inherentes a la soberanía real y no emanados por Roma, lo que provocó una serie de conflictos entre el poder real y pontificio, espacialmente en el siglo XVIII. Para más detalles, ver Góngora, Mario, 1957. Estudios sobre el galicanismo y la ilustración católica en América española. En Apartado de la Revista chilena de historia y Geografía, №125. Krebs, Ricardo, 1960. El pensamiento histórico, políticoy económico del Conde Campomanes. Santiago. Ed. De la universidad de Chile. Eyzaguirre, Jaime, 1995. Historia de las instituciones políticas y sociales de Chile:37 y 51. Santiago. Ed. Universitaria. Villalobos, Sergio. Silva, Osvaldo. Silva, Fernando. Estellé, Patricio. 2001. Historia de Chile: 188 y ss. Editorial Universitaria. Orlandis, José. 1998. Breve Historia del Cristianismo. 147 y ss. Santiago. Editorial Universitaria. Santiago. Campos Harriet, Fernando. 1983. Historia Constitucional Chilena: Ias instituciones políticas y sociales:51 y sss. Y 260 y ss. Santiago. Editorial Jurídica de Chile. Santiago.

23 La negativa de reconocer a Chile como sucesor de España en sus derechos, y pese a las reiteradas insistencias, fue, probablemente, porque de reconocer al gobierno chileno, debía extenderlo a las demás repúblicas, y porque el argumento a base del derecho de sucesión les debió parecer débil, puesto que estaba en conocimiento de que los gobiernos querían dejar atrás todo vestigio que los vinculara con España.

${ }^{24}$ Eyzaguirre, Jaime.1995: 37 y ss. 51. Villalobos, Sergio y otros. 2001:188 y ss. Campos Harriet, Fernando. 1983: 51 y sss. Y 260 y ss. 
otra ultramontana. ${ }^{25}$ Dicha transformación conllevó que la Iglesia exigiera su libertad. Para ello, sin embargo, era necesario dejar atrás el patronato, pues constituía una verdadera esclavitud al poder civil.

Por su parte, los gobiernos liberales se aferraron todavía más a su pretensión de conservar el patronato y regalías, porque de esa manera tenían sometida a la Iglesia bajo su poder. $^{26}$

Lo más absurdo del escenario que se abría con esta discusión era el hecho de que el clero chileno, de aceptar el regalismo, debía reconocer al Estado de Chile como sucesor de la Corona española, y como tal, de todos sus derechos. Se debía admitir así que el Presidente de la República era Vicario de Cristo, y merced a ello podía investir obispos y dar licencia para confesar, entre otras cosas. Es decir, al Presidente le estaría permitido gozar de los derechos propios del Papa. ${ }^{27}$ Absurdo era también que el Estado se sintiera heredero de los reyes de España, toda vez que a los gobiernos y a un sector de las clases dirigentes no les bastaba la independencia política de la Corona, sino que pretendían dejar atrás todas las costumbres, instituciones y formas de organización españolas, entre ellas la de la Iglesia.

Las posiciones de los bandos en la cuestión del patronato y regalías se radicalizaron progresivamente. A su vez, el gobierno iniciaba un proceso de hostigamiento al clero ultramontano, entre los que se encontraba monseñor Orrego, a quien se le prohíbe la salida del país en razón de derechos que nadie le había concedido.

Por su parte, Orrego luchaba desde el púlpito y a través de la prensa católica por la independencia de la Iglesia, pretensión que consideraba perfectamente válida porque en los estados funcionaba una serie de instituciones sociales, jurídicas, comerciales y políticas, entre otras, que se regían por sus propias normas, sin que por ello se atentara contra la soberanía y la Constitución.

El papel desempeñado por monseñor Orrego en estas luchas fue protagónico. Como teólogo y jurista supo bien cómo defender la postura de la Iglesia. Arguyó que el patronato y demás regalías no sólo eran un error, sino que además eran incompatibles con el derecho canónico, pues las Leyes de Indias, que contemplaban el patronato, quedaban sin valor alguno frente a las nuevas normativas de la República. ${ }^{28}$ Como consecuencia de la negación del

25 En relación con la necesidad de independizar la Iglesia del Estado es importante el papel jugado por el sacerdote argentino Castro, quien fue el primero que declaró la lucha al regalismo en Chile, influyendo fuertemente en monseñor Valdivieso, Salas, Larraín y Orrego. Para más detalles, ver Araneda Bravo, Fidel. 1986. Historia de la Iglesia en Chile. Santiago. 456 y ss. Ediciones Paulinas. Vergara, Rodolfo. 1914. Vida del ilustrísimo señor Joaquín Larraín Gandarillas.131. Santiago. Imprenta y Encuadernación Chile.

26 Recordemos, entre otros, el episodio de la vacancia arzobispal en Santiago, en el cual Domingo Santa María por todos los medios intentó que su candidato regalista fuese el arzobispo. Para ello, se fundamentó en las Leyes de Indias, señalando que eran parte de la legislación nacional. Para más detalles, ver: Araneda, Fidel. 1986: 571 y sss. Villalobos, Sergio y otros autores. 2001: 690 y ss. Encina, Francisco. 1983-1984: 113 y ss.

27 En relación con este punto se ha seguido a Krebs, Ricardo.1981: 45 y ss.

28 Editorial del 18 de junio de 1883. La Diócesis. 60 patronato y regalismo, daba a entender claramente que la supremacía sobre la Iglesia no la tenía el Estado, sino, por el contrario, el Papa, condenando de paso el nacionalismo eclesiástico.

Sin perjuicio de lo ya expuesto, donde la postura de monseñor Orrego contra las tendencias de los gobiernos liberales es totalmente visible fue en la "cuestión del sacristán", hecho donde le cupo una actuación destacada y que, a su vez, constituyó un hito que cambió la historia política de Chile.

\section{Cuestión del sacristán" y la Sociedad Santo Tomás de Cantorbery. ${ }^{29}$}

Si se analiza detenidamente la "cuestión del sacristán", ocurrida durante el gobierno de Manuel Montt - fuerte defensor de los privilegios del patronato-, podemos concluir que fue un asunto casi doméstico. Sin embargo, este incidente fue el que encendió la hoguera del conflicto político-religioso chileno.

“...Antes de la cuestión del sacristán, eran visibles... los síntomas de esa rebeldía teológica que formará, por algunos lustros, el alma de la religión liberal en Chile; pero sólo a partir de 1861 comienza ese movimiento espiritual a ejercer una acción indirecta, pero eficaz en la marcha de la política...." 30

Los hechos fueron los siguientes: sucedió que un empleado de la catedral, Pedro Santelices, se insolentó contra su jefe, el sacristán mayor, presbítero Martínez, quien lo destituyó del servicio. Seguidamente, Santelices se quejó de la medida ante el cabildo metropolitano, que lo reincorporó. Frente a ello, el presbítero Martínez reclamó al vicario subrogante, quien confirmó la expulsión. Dos canónigos del cabildo se negaron a acatar el fallo y decidieron apelar ante el obispo de La Serena, Justo Donoso. El vicario les concedió la apelación, pero sólo en el efecto devolutivo; esto es, sin suspender la aplicación del fallo. Los canónigos rebeldes, Meneses y Solís de Ovando, pidieron al arzobispo de Santiago, monseñor Rafael Valentín Valdivieso, que se las concediera en ambos efectos, pero éste se negó. Ante ello, los dos canónigos interpusieron el Recurso de Fuerza ante la Corte Suprema, que en definitiva acogió la petición.

Valdivieso recurrió al Presidente Montt para que, cómo protector de la Iglesia, interviniese. Sin embargo, el Presidente se excusó argumentando que el Poder Judicial era independiente. El arzobispo Valdivieso, frente a tal estado de cosas, señaló que no podía obedecer a la Corte.

29 Es importante señalar que el análisis que se realice de la "cuestión del sacristán" será hecho como antecedente de la prohibición de salida del país de Orrego, como desarrollo de su pensamiento ultramontano y como causa de la lucha entre católicos y liberales.

A su vez, se debe hacer notar que existen otros antecedentes que contribuyen a entender las posturas de los bandos en lucha y que claramente muestran los ánimos y argumentos de las partes. Sin embargo nos extenderíamos en demasía en situaciones que si bien son importantes, no hemos considerado relevantes para esta investigación.

Para más detalles ver Eyzaguirre, Jaime. 1995:115 y ss. Araneda Bravo, Fidel. 1983: 450 y ss. Edwards, Alberto. 2001: 107 y ss.

30 Edwards, Alberto. 2001:139. 
Ésta, por su parte, insistió al arzobispo que debía conceder el recurso en ambos efectos, bajo la pena de extrañamiento.

Gravísima era la situación en que se encontraba la máxima autoridad de la Iglesia chilena. Se preguntaba qué hacer, si cumplir con lo ordenado por la Corte, y de paso reconocer tácitamente el patronato; o bien, luchar hasta las últimas consecuencias. Tenía certeza de que la resolución que tomara determinaría en adelante las relaciones de la Iglesia con el Estado. Por ello llamó a sus consejeros, entre ellos al futuro obispo Orrego.

Durante la reunión, los sacerdotes se mantuvieron todo el tiempo callados, pues no estaban seguros de qué postura tomar, salvo José Miguel Arístegui, quien consideró que lo menos dañino era acatar lo ordenado por la Corte. Ante tales acontecimientos, los sacerdotes acordaron meditar el asunto y reunirse otro día. Pero Orrego, intranquilo y reprochándose a sí mismo por haberse mostrado "...cobarde en la reunión, quedándose sin manifestar su opinión que era francamente contraria a la del Sr. Arístegui", ${ }^{31}$ se dirigió nuevamente a casa del prelado para expresarle su parecer.

Cuando los sacerdotes se volvieron a reunir, monseñor Valdivieso ya había tomado una decisión a la luz de la posición de Orrego, determinación que implicaba desobedecer a la Corte, ir al destierro e iniciar la batalla por los derechos de la Iglesia.

Paralelamente, el Presidente Montt había captado que al Arzobispo no podía aplicársele la pena de extrañamiento, pues ello provocaría grandes disturbios. Fue así que a través de una serie de conversaciones y negociaciones se logró que los canónigos se desistieran del recurso. ${ }^{32}$

¿Pero qué significado tuvo este acontecimiento? ¿Por qué tanta importancia dada a un hecho casi doméstico?.

Se hizo evidente para la opinión pública de la época la postura del arzobispo Valdivieso y de su consejero Orrego: la no aceptación de prácticas regalistas. Su actitud firme y decidida descolocó a los gobernantes y al propio Poder Judicial al desobedecer su fallo. De paso, Valdivieso, con su determinación, desconocía el juramento que había prestado al tomar posesión de su cargo de obedecer las leyes nacionales.

Seguidamente la ciudadanía se dividió entre aquellos que apoyaban sin restricciones al Arzobispo y los que defendían las prerrogativas del poder civil, principio base del sentimiento liberal. Asimismo, los partidos políticos optaban por una u otra tendencia. ${ }^{33}$

Al entablar la batalla, Valdivieso mostró que un gran sector de la Iglesia estaba decidido doctrinariamente a no aceptar el regalismo y provocó al interior del clero la separación entre ultramontanos y regalistas. Más aún, como efecto de la "cuestión del sacristán", Valdivieso fundó la Sociedad Santo Tomás de Cantorbery, cuyo primer presidente fue

31 Ramírez, Juan Ramón. 1911. Vida del llustre Obispo chileno Dr. Don José Manuel Orrego y Pizarro. 90. Santiago. Imprenta y encuadernación Chile.

32 Para más detalles de la "cuestión del sacristán", ver Eyzaguirre, Jaime. 1995: 117 y ss. Araneda Bravo, Fidel. 1983: 493 y ss. Edwards, Alberto. 2001: 113 y ss. Villalobos, Sergio y otros. 2001:550 y ss.

${ }^{33}$ Así, el Partido Conservador se convirtió en el defensor de los derechos de la Iglesia, iniciando con ello la división del monttvarismo.
José Manuel Orrego. En ella, los asociados se comprometieron bajo juramento a no entablar el recurso de fuerza y a defender el dogma de la independencia de la Iglesia en su régimen espiritual. ${ }^{34}$

La creación de la Sociedad Santo Tomás de Cantorbery fue considerada por el gobierno como una intervención en la soberanía nacional e inició por ello, a través de la prensa liberal, una serie de ataques al catolicismo. A Orrego no le quedó más remedio que salir en defensa de los propósitos benéficos que perseguía la Sociedad y los medios legítimos que utilizaban para lograrlo. Señaló: “La Sociedad... no tiene ni puede tener por objeto la rebelión contra las autoridades del Estado. Es una asociación pacífica, inofensiva que se propone propagar y defender por todos los medios legítimos uno de los dogmas católicos, cuyo olvido e ignorancia ha causado males de gravísimas consecuencias. Entre los medios que se propone emplear para conseguir este fin... será la discusión razonada... de los fundamentos sobre que descansa el dogma de la independencia y libertad de la Iglesia...".

Como consecuencia, se produjo en la masa del país un fenómeno espiritual que Alberto Edwards entendió del siguiente modo:

“...el conflicto teológico va a popularizar la política, y en adelante los hombres de gobierno, los directores de la opinión tendrán que tomar en cuenta, cada día más, las fuerzas espirituales nacidas del choque entre la tradición religiosa y social, y el espíritu de los tiempos modernos...". ${ }^{35}$

En adelante, Orrego se presentó públicamente como un luchador por los derechos de la Iglesia, contrario al liberalismo y a las tendencias secularizadoras, y opositor al regalismo y al derecho de patronato, lo que explica los diversos conflictos e incidentes que mantuvo con los gobiernos durante su obispado

\section{UNA APROXIMACIÓN AL OBISPO JOSÉ MANUEL ORREGO}

\section{Sacerdote, profesor y teólogo}

José Manuel Orrego Pizarro nació en Quillota en abril de 1818. Fue hijo de Agustín Orrego y de Petronila Pizarro. Contando con dos años de edad, su padre falleció. La joven viuda, en compañía de sus pequeños hijos, fue amparada por doña María Josefa Orrego, hogar en el cual creció el futuro obispo de La Serena.

Sus primeros estudios los realizó en el convento de San Francisco, en la ciudad de Santiago, y en el año 1834 fue trasladado al colegio particular dirigido por Martín Urrutia, en calidad de alumno externo hasta 1835 . En ese período se manifestó su inclinación piadosa, inquietudes espirituales y su vocación sacerdotal. Al año siguiente, recibió de manos del que pronto sería el primer arzobispo de Santiago, Manuel Vicuña, la primera tonsura y cuatro órdenes menores. ${ }^{36}$

\footnotetext{
34 Estatutos de la sociedad en Revista Católica 6 de septiembre de 1856.

5 Edwards, Alberto. 2001: 134.

36 Ramírez, Juan Ramón. 1911: 1- 13.; Araneda Fidel. 1986:444.
} 
Seguidamente, decidió estudiar filosofía en el convento de Santo Domingo, donde destacó por su talento. ${ }^{37}$ En esa época conoció a Manuel Montt, quien entonces era rector del Instituto Nacional, y como tal examinó a Orrego, cuya inteligencia lo impresionó. ${ }^{38}$ Posteriormente, ingresó al Seminario Conciliar y fue alumno aventajado en las cátedras de Teología Dogmática y Derecho Canónico dirigidas por los obispos Hipólito Salas y Justo Donoso, respectivamente.

En el transcurso de 1841 recibió todas las órdenes sacerdotales. Ese mismo año inició su desempeño como profesor de teología y de derecho del Seminario, siendo nombrado rector de dicho establecimiento en $1850 .{ }^{39}$

Paralelamente, Montt, quien ya era Presidente de Chile en el decenio de los 50', estaba preocupado de la instrucción pública y deseaba realizar reformas al respecto. Estimó que el más idóneo para llevar a cabo dicho proyecto era Orrego. De él ya tenía una excelente impresión, precisamente porque años antes lo había calificado y considerado un alumno sobresaliente. ${ }^{40}$ Por ello es que lo designó rector del Instituto Nacional. No obstante, dicho nombramiento:

...cayó como una bomba en el campo de los políticos liberales o liberalizados, entre los que se contaban algunos profesores del Instituto. Clamaron al cielo por qué, según ellos, se quería hacer un claustro monacal del principal colegio de Chile. ${ }^{41}$

Es más, los enemigos del rector se dirigieron directamente al Presidente Montt, exigiendo la salida de Orrego. Al gobierno no le quedó más que solicitarle su renuncia a finales de 1852. Sin embargo, el sacerdote se negó porque consideró que gracias a su gestión, el Instituto se encarrilaba. ${ }^{42}$ Tal negativa originó un pequeño pero no menos importante incidente con el gobierno, cuya consecuencia fue la progresiva ebullición de los conflictos entre católicos y laicistas por el dominio de las conciencias. La discusión se trasladaba, así, al plano de la enseñanza.

Dicho de otro modo, la permanencia de Orrego en el cargo de rector del Instituto Nacional entorpecía los planes secularizantes y monopólicos de los liberales en cuanto a determinar los métodos de enseñanza, planes de estudios y textos a leer. ${ }^{43}$

Montt se vio obligado, por la presión ejercida, a despedirlo. Pero el ministro del Culto, Fernando Lazcano, ante la negativa de Orrego, decidió renunciar a su cargo para que no fuera la misma mano la que firmara el decreto de nombramiento y de destitución. ${ }^{44}$ Finalmente, el asunto lo resolvió

\footnotetext{
37 Ramírez, Juan Ramón. 1911: 15.

38 Por decreto expedido durante el gobierno de Prieto, se estableció que todos los alumnos que quisieran habilitarse para seguir una carrera, debían rendir examen en el Instituto Nacional. Ibídem:14.

39 Guerrero Manuel. 1934. Crónicas del Seminario y Obispado de la Serena: 9. La Serena: Moderna; Errázuriz Crescente: 1934. Algo de lo que he visto: 33. Santiago: Nascimiento.

40 Encina, Francisco. 1983-1984: 80 y ss. Tomo XXIV y 185. Tomo XXVI.

41 Ramírez, Juan Ramón. 1911:15.

42 Ibídem: 39.

43 Cifuentes, Abdón. 1936. Memorias: 34 y ss. Santiago: Nascimiento.

44 Ramírez, Juan Ramón. 1911: 40.
}

el nuevo ministro, quien de manera sutil, informó que el cargo de rector del Instituto Nacional estaba vacante. ${ }^{45}$

Orrego comprendió que dicho ataque no respondía a un mero capricho de los liberales; por el contrario, tras el combate por destituirlo como rector del Instituto Nacional estaba la idea de secularizar la educación en Chile. Por ello, decidió fundar el Colegio de San Luis, que impartiría educación católica y científica, conciliando la fe y la ciencia. No obstante, y pese a que el Colegio rindió buenos resultados, como la fundación de la Sociedad Literaria de San Luis, ${ }^{46}$ que contaba entre a sus miembros a Abdón Cifuentes y Zorobabel Rodríguez, Orrego carecía por completo de olfato y tino para los negocios. ${ }^{47}$ Por ello, debió cerrar el colegio y realizar cesión de sus bienes por la cantidad de deudas que había contraído para la manutención del establecimiento. Pero a pesar del triste final, en este proyecto se manifiesta el carácter e ideas del futuro obispo de La Serena. Esto es, su tenacidad en la lucha por mantener la hegemonía del catolicismo en la sociedad chilena.

Por otra parte, en 1844 Orrego había recibido el diploma de bachiller en la Facultad de Teología y Ciencias Sagradas; a los tres años fue declarado por el gobierno Doctor de la misma Facultad. Asimismo, fue nombrado siete veces consecutivas Decano de Teología (1853-1867). ${ }^{48}$

Seguidamente, el arzobispo de Santiago, monseñor Valdivieso, en 1850 lo designó como uno de los miembros que deberían formar parte de la congregación de teólogos para determinar y definir el misterio de la Inmaculada Concepción. ${ }^{49}$ Dicho nombramiento recayó en Orrego porque formaba parte del grupo de eclesiásticos chilenos mejor preparados intelectualmente de la época. Prueba de ello fue que el informe elaborado por el prelado ocupó el segundo lugar entre los que se escribieron al respecto en el orbe católico, y mereció las felicitaciones del propio Papa Pío IX. ${ }^{50}$

Y al tiempo que ejercía como teólogo y profesor, debía dar cumplimiento a sus obligaciones sacerdotales. Sabemos que llevó a cabo trabajos apostólicos en los talleres de la iglesia de la Compañía; que fue cura rector de la iglesia San Lázaro; confesor de monseñor Valdivieso y de todas las órdenes religiosas de todos los monasterios. A su vez, durante el año 1849 emprendió viaje rumbo a la región de la Araucanía, con el fin de emitir un informe sobre el estado de las misiones católicas. ${ }^{51}$

45 Para más detalles del despido, vid. Ramírez Juan Ramón. 1911: 36 y ss.; Errázuriz Crescente. 1934: 34.

46 Cifuentes, Abdón. 1936: 38.

47 Errázuriz, Crescente. 1934: 33.

48 Para más detalles de su labor de pedagogo, vid. Ramírez Juan Ramón. 1911: 1-13; Guerrero Manuel. 1934: 9; Silva Cotapos Carlos. 1925. Historia eclesiástica de Chile: 297 y ss. Santiago: Imprenta San José.

49 Para más detalles de la participación de Orrego y demás miembros del clero, vid. Ramírez Juan Ramón. 1911: 34 y ss.; Araneda Fidel. 1986:470 y ss.

50 Ramírez, Juan Ramón. 1911: 35.; Guerrero Manuel. 1934: 9.; Araneda Fidel. 1986: 470 y ss.

51 En cuanto a su visita a la región y sus observaciones de la colonización alemana protestante en el sur de Chile, vid. Ramírez Juan Ramón. 1911: 52 y ss. En relación a las actividades apostólicas desarrolladas en la iglesia de la Compañía, vid. Vergara Rodolfo. 1914. Vida del IIImo. 
Quienes conocieron a Orrego, lo describieron como «... un hombre profundamente piadoso, de carácter suave y benévolo, muy querido por sus amigos y a quien no se le conocían enemigos. De bastante capacidad, sin ser, a mi juicio, sobresaliente». 52

Por su parte, su biógrafo Juan Ramón Ramírez nos relata que era un hombre muy popular, aunque el prelado muchas veces lo ignoraba; inteligente, sabio, virtuoso, enérgico y prudente; asimismo señaló que:

...en las circunstancias ordinarias y habituales se mostraba suave, comunicativo y asequible. Todos se hallaban en presencia del hombre familiar, modesto, campechano y podríamos decir bonachón. En las circunstancias solemnes y extraordinarias sus manifestaciones eran como explosión de un volcán largo tiempo adormecido; ostentábase el hombre de acero, incontrastable, tenaz; el impertérrito defensor de su dignidad y de su conciencia... ${ }^{53}$

Seguramente aquellos rasgos virtuosos de Orrego fueron los que llevaron a Valdivieso no sólo a nombrarlo su confesor, sino que también a escuchar sus consejos en asuntos tan importantes como las reformas de los conventos regulares y en la debatida "cuestión del sacristán». ${ }^{54}$

Paulatinamente, Orrego se perfiló como parte del llamado "clero batallador ultramontano», 55 junto al arzobispo de Santiago y los obispos Hipólito Salas y Joaquín Larraín, quienes desde sus púlpitos lucharon por la libertad e independencia de la Iglesia.

\section{Orrego: Impulsor de la prensa católica}

Durante el gobierno de José Joaquín Pérez, el universo católico chileno sintió la necesidad de contar con una prensa católica que contrarrestara los efectos de los periódicos de tendencia liberal.

Los periódicos de Santiago «El Ferrocarril» y «El Progreso», y los de Valparaíso «El Mercurio» y «El Comercio», se inclinaban al liberalismo y atacaban constantemente a la Iglesia y sus valores. ${ }^{56}$

El clero seguramente temió que los lectores se fueran impregnando poco a poco del escepticismo político, social y religioso del que hacían gala dichos periódicos. Orrego comprendió que se requería fundar un gran periódico católico, porque si bien existía la "Revista Católica» ${ }^{57}$ desde 1843, en la cual escribieron plumas tan diestras como la de

Don Joaquín Larraín Gandarillas, Arzobispo titular de Anazarba: 151 Santiago: Universitaria.

52 Errázuriz, Crescente. 1934: 33.

53 Ramírez, Juan Ramón. 1911: 19, 27, 80 y ss.

54 Para más detalles de la reforma de los conventos de regulares, vid. Ibídem: 84 y ss.; Araneda Fidel. 1986: 471 y ss

55 El ultramontanismo conllevó primeramente el reconocimiento de la autoridad suprema del Papa, lo cual significa que sobre éste se edifica la Iglesia, la cual se centraliza en torno al Pontífice, dejando atrás los nacionalismos eclesiásticos y preconizando la Infalibilidad del Santo Padre, reconocida posteriormente en el Concilio Vaticano I.

56 Silva Cotapos, Carlos. 1925: 301.; Araneda Fidel. 1986: 515.

57 La Revista Católica fue creada durante el arzobispado de monseñor Vicuña, siendo sus fundadores los prelados Valdivieso y Orrego. Barrios Valdés Marciano. 1992. Chile y su Iglesia, una sola historia: 102 y ss. Santiago: Salesiana.
Valdivieso, Salas, Larraín Gandarillas y la de él mismo, ella sola ya no bastaba, toda vez que los periódicos eran los que la sociedad letrada leía. ${ }^{58}$

Por otra parte, la Revista Católica tenía como principal objetivo uniformar los criterios del clero y mostrar a los párrocos de provincias lo que debían pensar en cualquier tema de importancia. ${ }^{59}$ Así, difícilmente podía constituir un medio para defender al catolicismo frente a las tendencias liberales reformistas.

En otras palabras, el progreso de la sociedad dirigido por la visión moderna y las exigencias de la época, hicieron imperioso para los católicos el apertrecharse de las mismas armas que los liberales. De esta manera, Orrego junto con Joaquín Larraín Gandarillas y Manuel José Irarrázabal fundaron el primer periódico católico, que llamaron "El Bien Público», ${ }^{60}$ impreso que circuló dos veces por semana y que al poco tiempo fue sustituido por «El Independiente».

La fundación del periódico por iniciativa de Orrego nos revela su ímpetu batallador y su valiente actitud para contraatacar a los periódicos liberales. Incluso más, el obispo pretendió, con la creación de la prensa católica, reafirmar los valores cristianos en los que descansaba la base cultural de la sociedad chilena.

Pero la tarea de Orrego de promover la prensa católica no se quedó ahí y prosiguió. Siendo obispo de La Serena, fundó en 1871 «El Correo del Sábado», semanario redactado por los profesores del seminario diocesano. Posteriormente, se transformó en «El Correo de La Serena», y en 1882 tomó el nombre de "La Diócesis», momento en que el conflicto entre católicos y laicistas era manifiestamente explícito. En otras palabras, el cambio de nombre respondió a la necesidad de contar con una publicación católica marcadamente combativa. De hecho, el primer editorial señalaba:

...dada la situación que se encuentra la religión católica se ve obligado a hacer una lucha incesante contra las falsas ideas contemporáneas. La religión es la depositaria de toda la verdad. Y para ello necesita un medio por el cual se deje oír, a fin de defender sus hijos... para ello utilizará los mismos medios que usa para atacarlas: la prensa. ${ }^{61}$

Además,

...la prensa ejerce un influjo grande en las ideas y en las costumbres de la sociedad. De ahí la importancia de que la prensa sea movida por verdaderos intereses de los pueblos, como la justicia y los derechos. ${ }^{62}$

Claramente, monseñor Orrego supo entender que la prensa podía ser utilizada como arma y herramienta de defensa y de difusión de las ideas católicas, entre ellas la de combatir al regalismo y el Patronato heredado de España.

\footnotetext{
58 Silva Cotapos, Carlos. 1925: 301.

59 Errázuriz, Crescente. 1934: 142.

60 Ibídem: 302.; Araneda Fidel. 1986: 515; Cifuentes Abdón. 1936:

61 1882. La Diócesis 1.

62 1883. La Diócesis 77.
} 68. Vol. I. 
Presentación para Obispo de La Serena y las dificultades para prestar juramento civil

El 22 de febrero de 1868 falleció el obispo de La Serena, monseñor Justo Donoso Vivanco, considerado uno de los dignatarios más doctos del siglo XIX. ${ }^{63}$ Muerto el prelado, los canónigos de la catedral de aquella diócesis debían elegir un Vicario Capitular en la sede vacante. Sin embargo, ello no fue posible de inmediato, porque no lograron llegar a un acuerdo en el nombre. Por lo anterior, la designación recayó en manos del arzobispo Valdivieso, quien además contaba con facultades para ello.

Valdivieso, que ya había enfrentado al poder civil en la "cuestión del sacristán», quería evitar nuevos roces con el gobierno. Por ello se acercó al Presidente José Joaquín Pérez y le dijo: «Yo nombraré Vicario Capitular al mismo eclesiástico que su excelencia desee presentar para obispo». El Presidente contestó: "Mi candidato es Orrego». ${ }^{64}$ Logrado el acuerdo entre ambas potestades, Valdivieso propuso ante la Santa Sede a Orrego como candidato a obispo.

Sin embargo, Orrego, consecuente con su ideario ultramontano, no deseaba el cargo de obispo porque de hacerlo debía jurar observar la Constitución y las leyes del país, las que contenían normas que eran contrarias a la libertad e independencia de la Iglesia. ${ }^{65}$ Por lo demás, el futuro obispo debió tener muy presente la condena que el Papa Pío IX había hecho a monseñor Valdivieso por prestar dicho juramento cuando asumió tal investidura. ${ }^{66}$

Frente a los reparos de Orrego, el arzobispo Valdivieso inició negociaciones con el gobierno a fin de llegar a una solución para evitar un incidente, y de paso, el descarte de su candidato a obispo. Del resultado de ellas, el gobierno prometió allanarse a la fórmula que propusiera la Santa Sede. Al parecer, la solución planteada fue que Orrego al asumir primero como vicario capitular y luego como obispo jurara simplemente la observancia de la Constitución, ${ }^{67}$ arreglo que fue aceptado por éste.

63 Araneda Fidel. 1986: 552.

64 Silva Cotapos, Carlos. 1925: 297.

65 Campos Harriet, Fernando. 1983: 362

66 La censura papal señaló: «...el juramento prestado por ti debe tenerse por... ilícito y nulo; porque en la fórmula de dicho juramento no sólo se promete reconocer el derecho de patronato..., además, se promete por la expresa fórmula, no dar cumplimiento a las disposiciones de los sumos pontífices, sin la venia o exequátur de la potestad civil...». Carta del 6 de julio de 1854 del Papa Pío IX a Valdivieso, citado en Araneda Fidel. 1986: 468.

67 Ramírez, Juan Ramón. 1911: 164. No obstante lo relatado por Ramírez, no estamos seguros de que la Santa Sede haya propuesto dicha solución. Lo anterior, porque en 1848 acreditó credenciales ante el Vaticano la misión Irarrázabal, la que tuvo como objeto lograr que se reconociera el derecho de Patronato y demás regalías a Chile, y que se firmara un Concordato entre ambos Estados. La Santa Sede se negó a ello debido al controvertido juramento que debían hacer los prelados al asumir su investidura.

Posterior a ello, bajo la Presidencia de Montt en 1861 se insistió, casi en los mismos términos, en la preparación de un Concordato, que también fracasó.

Por ello no nos parece posible que la Curia romana propusiera tal solución. Salvo que la fórmula utilizada por Ramírez de simple juramento implicara reserva de derechos.

Para más detalles de proyectos de Concordatos, vid. Araneda Fidel. 1986: 456 y ss. y 482 y ss.; Eyzaguirre Jaime. 1995: 115.
Paralelamente, el Congreso Nacional reunido presentó al Presidente de la República la terna para llenar la silla obispal de la diócesis de La Serena, en la que ocupaba el primer lugar José Manuel Orrego. Por su parte, Valdivieso instruía el proceso o información canónica del candidato a la Santa Sede.

A principios de 1869 la Santa Sede nombró a Orrego como nuevo obispo de La Serena. Curiosamente, mientras se organizaba la ceremonia en la que el nuevo obispo recibiría el palio y las bulas de consagración, el gobierno olvidó la promesa hecha con el arzobispo de Santiago relativa al juramento.

Ante estos sucesos Orrego inició una ronda de conversaciones con el ministro del Culto, Blest Gana, para hallar una fórmula de juramento, pero fueron inútiles porque este último se presentó como un regalista intransigente. Orrego debió ceder, y juró guardar la Constitución y las leyes, pero no $\sin$ antes dar un golpe a las tendencias regalistas de los gobiernos chilenos, pues realizó una reserva de derechos, declarando que no consideraba leyes del país las que fueran opuestas a su conciencia y a la independencia de la Iglesia Católica.

Desde ese momento, los liberales y secularizadores seguramente tuvieron muy claro que Orrego sería un gran opositor a sus intereses. El incidente acaecido mientras era rector del Instituto Nacional parece casi anecdótico frente a la postura asumida en su juramento. Es más, los había retado, dando prueba suficiente de que defendería el catolicismo, sus instituciones y derechos a como diera lugar. Inevitablemente, se preparaba el camino para las grandes disputas por el dominio de las conciencias y la base cultural de los chilenos y de los serenenses.

\section{El obispo batallador, la vacancia arzobispal y el candidato regalista Taforó}

Instalado en su diócesis, Orrego se volcó a cumplir con las tareas que le imponía su investidura. Inició la visita pastoral por su jurisdicción, la que no se realizaba hacía muchos años, por la ancianidad de su antecesor, a fin de conocer el real estado de las parroquias y las necesidades de sus fieles. Probablemente por esa gestión dotó a la diócesis de una congregación moderna de religiosos y de infatigables misioneros para evangelizar las parroquias: los Hijos del Inmaculado Corazón de María. Vio también la necesidad de establecer en Copiapó un Seminario, el que determinó dejar a cargo del futuro obispo Guillermo Cárter, para que se educara la juventud de esa provincia.

Observó a su vez la devoción que existía entre los fieles de la zona a la imagen de la Virgen María, bajo el título de Nuestra Señora del Rosario de Andacollo. Por ello, emprendió la tarea de construir una basílica consagrada a la Virgen.

Por otra parte, renovó el Seminario Conciliar de La Serena organizando el cuerpo de profesores con sacerdotes y seglares de reconocida capacidad científica. ${ }^{68}$

68 Para más detalles de las obras en el obispado de La Serena, vid. Guerrero Manuel. 1934: 10 y ss.; Silva Cotapos Carlos. 1925: 304 y ss.; Ramírez Juan Ramón. 1911: 205 y ss. 
Efecto de la transformación es que se duplicó el número de estudiantes en el establecimiento, a la par que disminuía considerablemente el alumnado en el Liceo de La Serena. Ante ello, los liberales de la diócesis iniciaron una campaña de propaganda contra el catolicismo obteniendo buenos resultados. Muchos padres de familia se hicieron eco de las críticas y dispusieron el retiro de sus hijos del Seminario. ${ }^{69}$

Progresivamente las disputas entre los liberales secularizantes y los católicos empezaban a aflorar. Prueba de ello es que el gobierno, consciente de que Orrego era su opositor, le negó injustificadamente proveer las vacancias que se produjeron en el Cabildo eclesiástico, las que sólo fueron llenadas durante el gobierno de Balmaceda. ${ }^{70}$

Con el correr del tiempo, diversos incidentes que podríamos calificar de domésticos y artificiales aumentaron los roces entre el prelado y los gobiernos liberales. Así, el asunto acaecido en 1874 en el Liceo de La Serena, a propósito de un sermón pronunciado por el sacerdote Marcos Domínguez que atacó a la masonería, provocó tal revuelo que el rector del establecimiento, José Gorroño, prohibió el ingreso del religioso.

Al tomar conocimiento de los sucesos, Orrego solicitó al capellán del liceo, Buenaventura González, que renunciara a su cargo. Pero Gorroño no dio curso a la renuncia, sino que pidió la destitución del capellán por abandono de sus funciones, cuestión que fue decretada por el Presidente de la República. ${ }^{71}$ El Obispo, molesto por la actitud del rector y del gobierno, prohibió al clero realizar clases o retiros en el liceo porque con ello quería velar por la libertad de los sacerdotes.

Sin embargo, el padre Feliú desobedeció a su prelado y aceptó el cargo de capellán del establecimiento. ${ }^{72}$ Orrego, apoyado por la unanimidad del clero, pidió al provincial del religioso que lo separara de sus funciones, cuestión que se hizo inmediatamente. Luego protestó ante el gobierno y el rector por «...las injurias... provenientes de una persona conocida y responsable». ${ }^{73}$ Sin duda aludía a Gorroño y sus partidarios.

Los liberales organizaron un meeting para protestar por la actitud del Obispo, por considerarlo «...rebelde contra el Estado», y por "...perseguidor de los altos intereses religiosos». ${ }^{74}$ Tras la maniobra de los liberales, del gobierno y del rector del Liceo se pretendía hacer creer a los serenenses que Orrego estaba en contra de la enseñanza religiosa. Pero la protesta fracasó, porque los católicos comprendieron

\footnotetext{
69 Ramírez, Juan Ramón. 1911: 222 y ss.

70 Sabemos que durante los años 1869 y 1885, Orrego insistió constantemente al gobierno, por medio del Ministerio del Culto, la necesidad de llenar dichas vacantes. Sin embargo, ellas no fueron provistas. Para más detalles, vid.: ANCH, Archivo del Ministerio de Relaciones Exteriores. Vol. 227, Ministerios de Justicia, Culto e Instrucción Pública, Correspondencia. Y edición del 28 de enero de 1879 № 880, El Correo de la Serena. Sección Periódicos. BNCH. Mic: PCH, p. 97.

71 Para más detalles, ver en BNCH las ediciones del 2 de mayo de 1874 № 188, 7 de mayo de 1874 № 190, año IV del periódico El Correo

72 1874. El Correo de la Serena 189.

73 Ibídem 197.

74 Ibídem 198.
} de la Serena. cuál era la situación; en cambio, se dirigieron a la casa de su prelado para dar una muestra de apoyo. ${ }^{75}$

Desde ese momento, el Obispo se impuso porque había desenmascarado al gobierno con la verdad. A su vez, logró mantener silenciados a los liberales por un buen tiempo. Así, alejó la marea laicista por lo menos en manifestaciones públicas.

En la medida que el siglo avanzaba, las tendencias en pugna se radicalizaban cada día más. Mientras que Orrego intentaba mantener el catolicismo como elemento esencial de la cultura en su diócesis, los gobiernos que se fueron sucediendo eran aun más liberales y secularizantes. EI Presidente Federico Errázuriz había entrado de lleno en el campo del liberalismo reformista. En 1876 le sucedió Aníbal Pinto, con quien se acentuaron todavía más las tendencias liberales del gobierno, lo anterior porque bajo su mandato, moría monseñor Valdivieso. El Cabildo eclesiástico de Santiago se reunía y designaba vicario capitular a Joaquín Larraín Gandarillas, nombramiento que fue rechazado por el gobierno de Pinto, ${ }^{76}$ el que a su vez preconizaba como arzobispo de Santiago a Francisco de Paula Taforó, conocido regalista, ${ }^{77}$ rebelde al viejo arzobispo muerto y despreciado por el clero ultramontano. Dicha candidatura estaba destinada al fracaso desde un comienzo, ello debido a que Taforó era hijo natural, lo que constituía un impedimento para obtener el palio obispal de acuerdo al derecho canónico. Con todo, los gobiernos liberales que se sucedieron en estos años apoyaron e insistieron en el nombramiento de Taforó ${ }^{78}$ porque cumplía con las condiciones necesarias -regalista y liberal- para colaborar como mediador entre el Estado y la sociedad chilena en la implementación del proyecto gubernamental tendiente a secularizar las instituciones y la vida cultural. Se creía, además, por parte de los liberales, que

75 Ídem.

76 El gobierno adujo, para argumentar su intromisión, la posesión del Derecho de Patronato.

77 Prueba de ello es el discurso dado por Francisco de Paula Taforó el 5 de noviembre de 1849 en el que se oponía a la realización de un Concordato entre Chile y la Santa Sede debido a que significaba renunciar al derecho de patronato. En: Sesiones ordinarias de la Cámara de Diputados. 1878-1887. Santiago. Id. Sesiones Extraordinarias. Sesiones de la cámara. 5 de noviembre de 1849.

78 En efecto el gobierno movilizó al cuerpo diplomático chileno en Perú y en Europa con el objetivo que Taforó fuese nombrado arzobispo. De hecho en Perú residía monseñor Mocenni, Delegado Apostólico y enviado extraordinario de la Santa Sede para Chile y Perú, quien ante la insistencia del representante chileno en ese país, ministro Godoy, de nombrar a Taforó, sugirió: “...la conveniencia de solicitar confidencialmente la aquiescencia de la Santa Sede, antes de hacer elección definitiva de la persona que había de serle presentada para Arzobispado vacante". Frente a tal sugerencia del delegado, Godoy expuso ante el Ministro del Culto, Amunátegui, “¿...a qué quedaría la intervención del gobierno, en la provisión del Arzobispado u obispado. Si aún la proposición del candidato no hubiera de hacerse sin la aquiescencia previa de la Santa Sede? La solicitud de la aquiescencia, como quiera que sea, importa renunciar a la prerrogativa de la elección. Archivo del Ministerio de relaciones exteriores. Legación de Chile en el Perú, Oficio del Ministro Godoy. Oficio 12 de julio de 1878. Lo descrito cobra relevancia en cuanto que por una parte, la Santa Sede manifestó la posibilidad de lograr un acuerdo al sugerir un candidato de consenso. Y por la otra, queda en evidencia que el gobierno chileno creía ser poseedor del derecho de patronato y que no estaban dispuesto a negociar un nombre. 
Toforó podría lograr que la Santa Sede reconociera a favor del Estado de Chile el Derecho de Patronato. ${ }^{79}$

Como era de esperarse en 1879 el candidato del gobierno Francisco Taforó fue rechazado por la Santa Sede. Blest Gana creía que el rechazo al candidato de gobierno se debía exclusivamente a la forma en que había sido designado para arzobispo de Santiago. Así informaba al presidente Aníbal Pinto:

"Como usted ve caemos en la cuestión del Patronato. El Papa, en efecto, desde sus primeras palabras, y el Cardenal Secretario de Estado, no ocultaron su antipatía por una forma de presentación que, aunque constitucional para nosotros, no era para ellos más que el uso de regalías, que si no eran toleradas por el gobierno del último Pontífice, éste no parece admitir si no se toma, lo que considera un acto de deferencia y cortesía, la medida de solicitar un acuerdo previo, aunque confidencial, sobre la persona que desea presentarle para alguna dignidad de la Iglesia. Es, pues, como antes le decía, la eterna cuestión del Patronato que surge con el gobierno nuevo del Vaticano, a la primera ocasión que se le presenta. La Santa Sede valiéndose de la tremenda oposición hecha al electo, ha encontrado la oportunidad muy buena para hacer sentir al gobierno su reprobación por la forma en que se ha presentado. El Papa y su secretario de Estado, me lo dijieron entonces y el señor Nina me lo repetía hoy, que la Santa Sede no conviene en que vengan a ponerle freno a un hecho consumado, como lo es nuestra elección constitucional para las presentaciones de dignidades de la Iglesia, obligándole a prestar su aquiescencia cuando para nada se le ha consultado previamente." 80

No obstante, el motivo oficial por el que se rechazó al candidato de gobierno por parte de Roma fue su defecto de natalicio, ${ }^{81}$ más, los antecedentes e información que tuvieron a la vista, esto el carácter rebelde, liberal y regalista de Taforó. Sin perjuicio de lo indicado, también fue decisivo el mecanismo mediante el cual fue electo Francisco de Paula Taforó, puesto que afectaba la autonomía que buscaba la Iglesia, esto es, la plena independencia de los poderes civiles.

Pese a ello la Curia romana dejó las puertas abiertas para negociar un nombre de consenso con el gobierno, ${ }^{82}$ lo que fue rechazado por las autoridades chilenas pues lo consideraban inviable.

79 Para más detalles ver: Documentos relativos a la presentación hecha a la Santa sede en 1878 por el Gobierno de Chile, del señor prebendado don Francisco y Paula Taforó para ocupar la sede vacante de la Arquidiócesis de Santiago. 1883. 16 y ss. Valparaíso. Ed. La Patria.

80 Santa María, Alfredo. (Sin fecha): Carta de Alberto Blest Gana al presidente Aníbal Pinto. 17 de Febrero de 1879.

81 “... Su Santidad, prescindiendo de las cualidades personales del expresado eclesiástico, no ha creído deber admitir la propuesta y conferirle la institución canónica porque habría debido dispensarlo de la irregularidad ex defectu natalium, impedimento del cual la Santa Sede no dispensa sino en rarísimos casos..." Documentos... 1883. 37. Relación escrita de los fundamentos del rechazo redactada por el Cardenal Nina al embajador chileno en Roma, Blest Gana.

82 Santa María, Alfredo. (Sin fecha) De Taforó a Casanova, en la correspondencia particular del presidente Santa María. En: Revista Chilena de Historia y geografía, Santiago. Ed. Universitaria. № 107-108 y 109. Carta de Blest Gana, ministro plenipotenciario de Chile en Roma, al presidente Aníbal Pinto. 17 de febrero de 1879.
La disputa entre los bandos enfrentados por las conciencias chilenas, como del nombre para arzobispo de Santiago, se vieron "postergadas» por la Guerra del Pacífico. ${ }^{83}$ Finalizada ésta, en 1881 se reinició una campal disputa retomada por el no menos liberal y secularizador, Domingo Santa María, recién electo presidente de Chile, quien impregnado del ideario regalista insistió ante la Santa Sede para que el candidato de gobierno rechazado en 1879, Francisco de Paula Taforó, fuese nombrado arzobispo de Santiago.

La insistencia del gobierno chileno en la candidatura de Taforó respondió a la pretensión de hacer valer el regalismo como derecho existente en la legislación nacional, que a juicio de las autoridades gubernamentales había sido rechazado arbitrariamente por la Curia Romana, situación que no se podía tolerar porque significaba una merma a la soberanía nacional. Incluso el presidente Santa María declaraba

“...Querer adueñarse del Estado a pretexto de imperar sobre la conciencia. Es una pretensión ridícula y absurda; hoy que el dogma de la soberanía nacional del pueblo tiene más convencidos secuaces que el intrincado de la encarnación del hombre Dios. Veo que no arribamos a acuerdo alguno y que la Santa Sede habrá de convencerse que no es posible pretender, ni sostener que la Iglesia viva independiente dentro del Estado y avasalle al estado haciendo de la Iglesia una potencia que tiene fauces para tragárselo todo". 84

Paulatinamente el asunto de la vacancia arzobispal se transformó en un asunto de Estado. Así, durante noviembre de 1881 el gobierno chileno, representado por su embajador en Roma Blest Gana, insistió oficialmente en la presentación Taforó para arzobispo de Santiago. A la Santa Sede no le agradó la insistencia en el mismo nombre, pues consideraba que el asunto había quedado concluido unos años antes. Más aún, debido a inconvenientes en la persona de Francisco de Taforó para acceder al arzobispado, esto es, defecto de natalicio, y por la forma en que se había elegido éste como candidato.

Sin embargo Blest Gana defendió la posición del presidente Santa María frente al Cardenal Jacobini indicando:

“... En mi réplica defendí con calor: $1^{\circ}$ la tesis de que, al tocar Ud. En la carta el asunto del señor Taforó, a querido dar a este negocio la solemnidad que corresponde y manifestar que el gobierno lo coloca entre los de más alto interés del Estado; $2^{\circ}$ que su Santidad no se ha pronunciado ni está comprometido con la respuesta que me hizo dar en 1879, porque esa respuesta no es otra cosa que una proposición confidencial hecha por el Papa al Gobierno de Chile, y que se encuentra en la imposibilidad absoluta de admitir..., $3^{\circ}$ que hasta ahora fuera de la acción diplomática, sólo ha oído la Santa Sede a los enemigos del sacerdote propuesto, es decir, que solo conoce las calumnias en

83 En esta investigación no se abordó el rol jugado por Orrego durante la guerra, ni los problemas que se suscitaron a propósito del nombramiento de capellanes para la guerra que se sostuvo son el arzobispado de La Plata (Sucre). Para más detalles, vid. Ramírez Juan Ramón. 1911: 236 y ss.; González Juan Ignacio. 1994. Iglesia y Fuerzas Armadas. Santiago: Universidad de Los Andes; Varas José Matte. 1983. Historia del Vicariato Castrense en Chile. Santiago: Vicariato Castrense.

84 Santa María, Alfredo. (Sin fecha) Carta de Domingo Santa María a Blest Gana, 11 de agosto de 1882. 
contra de él, y que debe al gobierno de Chile justicia imparcial y examen completo del negocio". ${ }^{85}$

Llama la atención los argumentos del ministro Blest Gana. En efecto, pone en tela de juicio los sistemas y mecanismos de elección de la Santa Sede, y pone en duda que la curia haya conocido de todos los antecedentes para tomar tal determinación, incluso asevera que sólo se ha tomado en consideración las opiniones e informes del clero ultramonatano, enemigos declarados de Taforó. Pese a lo anterior, la Santa Sede, en un hecho sin precedentes, ordenó un nuevo estudio del candidato del gobierno chileno: Francisco de Paula Taforó. Seguramente, tras tal determinación, estaba la esperanza que con ello se calmaran los ánimos gubernamentales chilenos, dando tiempo para buscar un nombre que satisfaciera los intereses de todos.

En tal contexto, la congregación de los Negocios Eclesiásticos, resolvió el 23 de febrero de 1882, proponer al Papa el envío de una delegado apostólico que investigara al candidato del gobierno chileno. La razón para ello, era la existencia de informes contradictorios respecto de la persona y obras de Taforó. ${ }^{86}$ La decisión fue comunicada a Blest Gana quien se opuso al envío aduciendo que retardaría la preconización, con funestas consecuencias. ${ }^{87}$ Pero el Papa

\footnotetext{
“...teniendo en cuenta, por una parte su anhelo de mantener buenas relaciones con los gobiernos de países católicos, y por otra, el gravísimo deber que le incumbía de no proveer los obispados sino con personas manifiestamente dignas, se mantuvo firme en su resolución. La delegación apostólica tendría un doble objeto: el uno general, de atender los intereses religiosos de los fieles; y el otro espacial, de informar a la Santa sede acerca de la persona presentada por el gobierno para la provisión del Arzobispado..." ${ }^{88}$
}

En este contexto, arribó en mayo de 1882 a Chile el delegado apostólico Celestino Del Frate, quien sólo tenía como atribuciones recopilar información del candidato de gobierno y velar por los intereses de los fieles. ${ }^{89}$

Mientras tanto, Orrego, que había logrado mantener su diócesis un tanto apartada del conflicto, se disponía a viajar en 1882 rumbo a Europa. Sin embargo, sorpresivamente, las autoridades gubernamentales le impidieron salir del país.

Desde ya nos surgen una serie de preguntas frente a estos hechos: ¿Por qué el gobierno prohibió especialmente a Orrego salir del país? ¿Qué motivos justificaron la medida? y ¿qué estaba ocurriendo en Chile a finales del siglo?

\section{OPOSICIÓN DEL GOBIERNO A LA SALIDA DEL PAÍS DEL OBISPO ORREGO}

Durante 1872 y 1874, monseñor Orrego realizó la visita pastoral por su diócesis. Era necesario conocer las viceparroquias, así como también los yacimientos mineros en

85 1883. Documento relativos a la presentación. 47. Carta de 28 de noviembre de 1881 a Santa María.

86 Vergara, Rodolfo. 1914:193.

87 Santa María Alfredo. Carta de Blest gana a Santa maría 21 de febrero de 1882 .

88 Vergara, Rodolfo. 1914. 194.

89 Boletín Eclesiástico, Vol. VIII, 739. activa explotación, donde había numerosos obreros. Para ello, se hizo acompañar de varios misioneros y él, personalmente, confesó y predicó continuamente. ${ }^{90}$

Durante la visita, el obispo contrajo un resfriado, cuya secuela fue una progresiva pérdida del oído, merma que desde 1882 era ya casi absoluta y sin remedio alguno que la detuviera.

Esta situación era verdaderamente deplorable. Sólo a voces destempladas podía el obispo comunicarse con los circunstantes y personas que necesitaran de sus consejos y resoluciones, y aun en asuntos delicados, sus palabras resonaban a larga distancia... ${ }^{91}$

Con el objeto de ser tratado por especialistas y poder así continuar efectuando sus labores de prelado satisfactoriamente, Orrego decidió viajar a Europa. El mismo viaje le permitiría cumplir, además, con la visita personal Ad Limina Apostolorum $^{92}$ ante el Papa.

En marzo de 1882 comunicó al ministro del culto, José Eugenio Vergara, su determinación de viajar; los motivos para ello y el nombre de los vicarios que lo reemplazarían en su ausencia. ${ }^{93}$

Orrego se encontraba en las vísperas de su viaje cuando recibió una nota del ministro Vergara. En dicha comunicación se le prohibía terminantemente separarse de su diócesis, con el argumento de que para abandonar el país era necesario solicitar «licencia» o autorización al gobierno, conforme lo prescribía el derecho canónico y civil. ${ }^{94}$

Frente a dichos argumentos, Orrego replicó al ministro señalando que tenía "...la íntima convicción de que no existe ley canónica o civil que obligue a un obispo católico de un país católico a moverse de su diócesis, sin la venia gubernativa». ${ }^{95}$ Sumado a lo anterior, le recordó que en 1869 se había ausentado del país para asistir al Concilio Vaticano I, dando sólo aviso al gobierno y sin observarse conflicto alguno con las autoridades civiles. ${ }^{96}$

El ministro del Culto, ante las observaciones del prelado, envió un telegrama al intendente de Coquimbo, Antonio Larraguibel, ordenándole que impidiera la salida de Orrego

90 Para más detalles de la visita pastoral de la diócesis de La Serena, vid. Ramírez Juan Ramón. 1911: 205 y ss.; Silva Cotapos Carlos. 1925: 304 y ss.

91 Ramírez, Juan Ramón. 1911: 275.

92 Los obispos, conforme al derecho canónico, están obligados a «presentar a la Santa Sede, cada cinco años, una relación del estado de su diócesis, y junto con ella, o por lo menos cada diez años, deben presentarse personalmente ante el Papa y verificar la visita ad limina apostolorum, o sea, a las basílicas de San Pedro en el Vaticano, y San Pablo extramuros». Valenzuela Valderrama Héctor. 1963. Manual de Derecho Canónico: 90. Santiago: Universitaria.

93 1882. "Aviso de salida del país de Orrego a Vergara, 20 de mayo". La Diócesis 5.

94 1882. "Telegrama de Eugenio Vergara a Orrego del 31 de marzo". La Diócesis 6.

95 1882. "La nota de respuesta de Orrego a Vergara, del 7 de abril". La Diócesis 6.

96 Orrego fue uno de los prelados chilenos que asistieron al Concilio Vaticano I, en que se definió el dogma de la infalibilidad papal. Su postura era favorable al dogma, pero estimaba que no era la oportunidad para declararlo. No obstante, una vez que la mayoría aprobó su declaración, Orrego lo aceptó sin reparos. Para más detalles, vid. Ramírez Juan Ramón. 1911: 199; Araneda Fidel. 1986: 516 y ss. 
de la diócesis utilizando la fuerza pública si era necesario, puesto que a criterio del gobierno no había solicitado autorización para emprender el viaje. A su vez, Vergara instruyó, calculadamente, al intendente de cómo debía dar cumplimiento a la orden. Le dijo:

...que se apersonara al señor Orrego y fuese sondeando poco a poco su ánimo, tratándolo primero con amabilidad, pero que si se manifestara persistente en sus propósitos le hiciera al fin pesar enérgicamente la voluntad del gobierno y su resolución de castigar la desobediencia... ${ }^{97}$

El intendente de Coquimbo, al parecer, no captó la astucia o diplomacia de Vergara. Se dirigió al Obispo y, sin mediar preámbulos, le hizo entrega del telegrama enviado por Vergara con la orden de impedir la salida.

Dicha orden exacerbó el ánimo de Orrego y prontamente le hizo saber a Vergara que no suspendería el viaje, toda vez que tenía comprado el pasaje hasta Panamá, añadiéndole que el gobierno carecía de facultad para impedir su itinerario. Agregaba «...Emplear la fuerza pública para violentar un obispo y quitarle su libertad de movimiento sin haber delinquido en lo más mínimo, es contrario a la Constitución y las leyes del país». ${ }^{98}$

Orrego estaba resuelto a viajar aun a riesgo de ser encarcelado. Y de hecho el 16 de abril de 1882 se aprontaba a salir rumbo a Coquimbo para embarcarse a Panamá; sin embargo, no le fue posible.

El intendente Larraguibel, obedeciendo las órdenes del ministro Vergara, hizo rodear el palacio episcopal por la policía. A su vez, impidió el paso de carruajes públicos o particulares a la casa del obispo con el objeto de evitar su traslado. Sumado a lo anterior, se prohibió a la empresa de Ferrocarriles en La Serena y Coquimbo, y en el puerto de esta última ciudad a todo tipo de embarcaciones, incluso a los buques de guerra de bandera extranjera, transportar a Orrego desde la diócesis a cualquier otro punto del país o el extranjero.

El conflicto, evidentemente subió de tono, puesto que Orrego estaba preso en su diócesis por una orden emanada del poder civil. Pese a ello, el obispo no se resignó ante tamaño vejamen y clima hostil, y decidió viajar a Santiago a enfrentar los hechos. Asimismo, preso de una gran congoja resolvió renunciar a su cargo.

\section{Reacciones y protestas}

Mientras tanto, en la ciudad de La Serena se suscitó una enorme protesta por la actitud del gobierno. La gente se preguntaba cuáles eran los motivos para prohibir tan arbitrariamente la salida de Orrego.

El naciente periódico "La Diócesis» de la ciudad de La Serena fue uno de los medios por los cuales los católicos serenenses dieron rienda suelta a sus iracundas protestas. En diversos editoriales y artículos del periódico, se expresó el descontento frente a la actitud "tiránica y caprichosa» del gobierno, como motivo principal de la prohibición de salida del país del dignatario. Se señaló, a su vez, que las

97 Ramírez, Juan Ramón. 1911: 277.

98 1882. "Telegrama de Orrego a Vergara, del 15 de abril". La Diócesis 6. medidas tomadas por el ministro del Culto obedecían también a otras causas. Por una parte, al regalismo que preconizaba tanto Vergara y el gobierno; y por otra, eran el reflejo de la venganza que el gobierno chileno hacía sentir por el rechazo de la Santa Sede de la candidatura de Taforó como arzobispo de Santiago, y, asimismo, eran fiel consecuencia del "despotismo del ministro».

Como ya se ha visto, el fundamento de Vergara para prohibir la salida del país a Orrego fue que no había solicitado autorización o licencia al gobierno, según indicaba el derecho canónico y civil. Es decir, consideraba a los prelados, en cierto modo, como empleados fiscales. Sin embargo, había un hecho cierto: los obispos no eran empleados públicos, y por tanto no dependían del gobierno. Es más, los obispos no eran nombrados por el Presidente de la República; la nación no los rentaba como parte del aparato administrativo y menos aún podían destituirlos. Los católicos serenenses señalaron que ni Orrego ni ningún otro obispo era empleado fiscal. De ser así, el Vaticano no habría rechazado la candidatura de Taforó, puesto que: «...El Papa es solamente quien tiene derecho a nombrar nuestros obispos, por más que agiten los partidarios del cesarismo civil». ${ }^{99}$

Asimismo, esta prohibición del gobierno fue juzgada por sus contemporáneos como un atentado a la Constitución, pues ésta garantizaba en su articulado «a todos los habitantes la libertad de permanecer, trasladarse o salir del territorio», ${ }^{100}$ por lo que la prohibición era caprichosamente arbitraria.

No obstante, la norma constitucional agregaba una excepción: "salvo que exista perjuicios a terceros». ${ }^{101}$ Los católicos serenenses se cuestionaron cuál podía ser dicho perjuicio, y concluyeron que ninguno. Por lo demás, correspondía al Poder Judicial y no al Presidente de la República determinar si eventualmente existían daños a terceros.

Finalmente, el argumento gubernamental se basó en el derecho de Patronato que tenía el Presidente en virtud de la Carta Fundamental, y por ello podía prohibir la salida del país a Orrego. Sin embargo, si el gobierno fundamentaba su resolución en el derecho de Patronato, debió recordar que éste no sólo establecía derechos, sino también una serie de deberes. Entre ellos el de «vigilar por la libertad y respeto de los ministros de la Iglesia y especialmente de los obispos», quienes en "su ejercicio son completamente independientes de la autoridad civil». ${ }^{102}$ Los católicos serenenses estimaron, por tanto, que la actitud del gobierno para con su prelado era manifiestamente discriminatoria y arbitraria.

Por lo anterior, el clero de La Serena manifestó de inmediato el apoyo a su obispo a través de una nota. En ella le hicieron saber que reaccionaban ante los «deseos tan injustos del gobierno", como también lo incentivaban a seguir luchando por la defensa e independencia de la Iglesia del gobierno laico y tiránico. Más aún, el clero llamó a todos los católicos a levantarse contra el gobierno y sus avances liberales que humillaban no sólo a sus prelados, sino también a los fieles. ${ }^{103}$

\footnotetext{
991882 “Editorial”. La Diócesis 1.

100 1833. Constitución Política de Chile. Cap. V. Artículo 12, N 4.

101 Ídem.

102 1882. La Diócesis 1.

103 1882. La Diócesis 1. № 5.
} 
Dichos llamados prontamente recibieron respuesta. El clero y las señoras de la ciudad realizaron una manifestación en La Serena, en la que se comparó a Orrego con San Pablo, en el sentido de estar siempre vigilante para atraer a los que se extravían y combatir a los enemigos de Dios. ${ }^{104}$

Por su parte, el clero de Copiapó hizo manifiesto su apoyo al prelado por medio de una nota, donde se lee:

...la noble actitud en el conflicto en que ha sido arrastrado por el gobierno de la República, nos ha colmado de gozo y encendido más en nuestros corazones el cariño y admiración y el respeto con que siempre hemos venerado a la persona... de nuestro prelado. Agregaban con orgullo: ...que Orrego siempre ha sido celoso en la defensa de los derechos de la Iglesia. ${ }^{105}$

A dichas protestas se sumaron las de las señoras católicas de Santiago. En ellas le hicieron saber lo orgullosas que estaban por su actitud defensora de los derechos y libertad de la Iglesia. ${ }^{106}$

\section{Estadía en Santiago}

Orrego se trasladó a la capital con el firme propósito de enfrentar al gobierno. Una vez más hizo saber al ministro del Culto que no solicitaría autorización alguna para emprender su viaje. Nuevamente, entonces, dio muestras de tenacidad y valentía.

Vergara, por su parte, realizó un extenso estudio de las leyes patrias como de la legislación de Indias. Quiso demostrar que el gobierno de Chile tenía el derecho de Patronato; y, por ello, la facultad de impedir la salida del país a Orrego, puesto que éste no había solicitado debidamente la autorización correspondiente.

Es más, le hacía saber al prelado que su inobservancia había quebrantado las relaciones con el Estado y, también, le señalaba que el gobierno no tenía la intención de impedir su viaje, sino que simplemente deseaba que se cumpliera con la legislación vigente. Añadía: «...que era un deber para los obispos residir en sus diócesis, tanto por la ley canónica y civil...». ${ }^{107}$ Para ello se basaba en la Recopilación de Indias. De acuerdo con su texto, los obispos sólo podían salir de sus diócesis con licencia de la autoridad, monarca o presidente, en razón del derecho de Patronato.

Finalmente, le recordaba que al asumir el obispado había jurado «...guardar y hacer guardar en el ejercicio del episcopado la Constitución y las leyes de la República», con lo cual reconocía la vigencia del derecho de Patronato. Pero olvidaba mencionar que Orrego había jurado con la salvedad de excluir todas las leyes que estuvieran en contraposición con su conciencia y con la Iglesia.

Pues bien, Orrego estimó que tanto vejamen lo humillaba no sólo como católico, sino también como chileno. Pensó, en ese momento, que las virtudes, si alguna vez existieron, se habían ido todas al basurero. La insistencia del

104 1882. "Sobre la manifestación y cartas de apoyo de las señoras de La Serena". La Diócesis 1. № 8.

105 1882. La Diócesis 1. № 9.

106 1882. La Diócesis 1. № 10

107 1882. La Diócesis 1. № 7. gobierno de prohibirle viajar constituía un abuso de poder, puesto que dicha resolución no provenía de los tribunales de justicia.

Es por lo anterior que el obispo replicó la nota de Vergara. Le recordó que la Legislación de Indias no era aplicable, puesto que desde la emancipación política se encontraba derogado todo el ordenamiento español. De lo contrario, agregaba Orrego, "...los herejes no pueden ser funcionarios públicos, son inhábiles». Es más, se preguntó: «... ¿̇se creerá ligado hoy por igual prohibición el Presidente de la República?». ${ }^{108}$

Por otra parte, añadió que por mandato de la Constitución el Presidente de la República estaba obligado a «observar y proteger la religión católica, apostólica y romana». Podemos colegir entonces de las palabras de Orrego que de cumplirse el mandato constitucional, Santa María y su gobierno carecían de la facultad de prohibirle la salida. Es más, había un deber hacia la Iglesia que estaba siendo vulnerado, que a juicio de los católicos estaba basado por meros caprichos de un gobierno tiránico y liberal.

LA PROHIBICIÓN DE SALIDA DEL PAÍS A ORREGO COMO MANIFESTACIÓN DE LA LUCHA POR LAS CONCIENCIAS

Es evidente que la prohibición de salida del país a Orrego constituyó una de las diversas manifestaciones de la lucha que se libraba por el dominio de las conciencias. Por un lado, el Estado deseaba contrarrestar la influencia de la Iglesia conservando las prerrogativas que tenía, entre las cuales estaban el derecho de Patronato y demás regalías. Por otro, la Iglesia batallaba por mantener su dominio cultural como elemento unificador de los chilenos, y por preservar su independencia del gobierno.

A su vez, es necesario tener en cuenta que la prohibición ocurre justo en una coyuntura muy negativa para las relaciones entre la Iglesia y el Estado. Precisamente, y tal como se ha comentado, durante 1879 , se comunicó al gobierno el primer rechazo de su candidato regalista, Francisco de Paula Taforó, como arzobispo de Santiago.

Este rechazo papal fue determinante para la disputa que se produjo entre laicistas y católicos, puesto que el presidente Domingo Santa María interpretó la decisión romana como un menoscabo a su autoridad y honor. Por lo demás, el rechazo significó para el gobierno un retroceso en su disputa por el dominio de las conciencias y tendencias culturales del país. Más aún, el gobierno estimó que se le desconocían sus derechos de patronato y que la Iglesia vulneraba su soberanía.

Este contexto explica la resolución del gobierno de prohibir la mentada salida del país, puesto que era uno de los medios que tenía para establecer supremacía sobre el catolicismo. Qué mejor entonces que impedir todo movimiento a Orrego, único obispo titular en ese momento en Chile, quien además era ultramontano.

108 Ídem. 
Por otro lado, el gobierno aprovechaba de vengarse de Orrego porque junto al vicario capitular de Santiago, Joaquín Larraín, era opositor declarado de Taforó. ${ }^{109}$

Asimismo, el momento de la disputa con Orrego era inapropiado porque, en un hecho insólito, el gobierno de Santa María solicitó a la Santa Sede la reconsideración del rechazo de Taforó. Increíblemente, la Santa Sede, para conservar las buenas relaciones con el gobierno chileno, envió un delegado apostólico con el fin de que informara sobre el candidato. El gobierno, en tal escenario, estaba obligado a representar el papel de Estado católico ante el Vaticano, con el fin de que Taforó fuese el elegido. Sin embargo, la persecución a Orrego, seguramente, causó una pésima impresión al delegado apostólico. Atento a estas circunstancias, el gobierno solicitó al comisionado monseñor Del Frate que mediara en el conflicto, antecedente que no deja de ser paradójico, puesto que la actitud estatal tuvo como intención demostrar su fuerza y supremacía sobre el mundo católico, pero debió recurrir a éste, como mediador, para poner punto final al problema. No obstante, ello es absolutamente comprensible, y no se puede considerar una contradicción en la política liberal, puesto que fue utilizado como medio para lograr sus objetivos.

Pues bien, el delegado apostólico, con ánimo conciliador y usando los amplios poderes de que venía investido, dispensó a Orrego de su visita ad limina. El obispo, ante ello, señaló: «Acato con toda sumisión y respeto la disposición de Roma; pero sepa Monseñor que si principia a ceder a la gente que nos gobierna muy pronto estará terminada su misión». ${ }^{110}$ Luego de ello, Orrego regresó a La Serena, donde fue recibido por el pueblo como un héroe triunfante.

Aparentemente, todo volvió a su orden. Orrego regresó a su diócesis y no emprendió el viaje. No obstante, los conflictos entre católicos y liberales continuaron en La Serena.

Como era de suponer, Orrego no estuvo conforme con la resolución del delegado apostólico. Si bien acató la decisión, lo cierto es que había sido obligado una vez más a transar con el gobierno laicista.

Por su parte, Santa María y Vergara debieron sentirse triunfantes. A pesar de que la solución había sido dada por la propia Iglesia, fue del todo favorable para ellos. En otras palabras, posiblemente entendieron que tácitamente se daba razón a sus argumentos. Y tal vez, por dicha solución, el gobierno fue aún más hostil con el prelado. Así, a vía de ejemplo, se puede señalar que el gobierno no proveyó las vacantes de canónigos de la catedral de la ciudad, aduciendo como fundamento que «mientras no se nombre a Taforó, no se nombrarán canónigos». ${ }^{111}$

\section{LAS LEYES LAICAS Y LA ACTITUD DE ORREGO}

Paralelamente al incidente ocurrido con el obispo Orrego, la ofensiva liberal liderada por Santa María buscaba tenazmente llevar a cabo una serie de reformas teológicas,

\footnotetext{
109 Errázuriz, Crescente. 1934: 267.

110 Ramírez, Juan Ramón. 1911: 310.

111 1882. La Diócesis 1. N 30
}

puesto que existía el temor de que el Papa no nombrara a Taforó como arzobispo de Santiago. ${ }^{112}$

En efecto, el 23 de noviembre de 1882 la Curia Romana comunicaba al Presidente de Chile que se rechazaba, por segunda vez, al candidato de gobierno, Francisco de Paula Taforó. Pese a ello, Roma dejaba, nuevamente, la puerta abierta para negociar la presentación de otra persona para ocupar dicho cargo. ${ }^{113}$ Sin embargo, ante la decisión papal que denegaba la promoción de su candidato, Santa María adoptó una política intransigente, amparada en el regalismo, expulsando al Delegado Apostólico. Acto seguido, se negó a proveer los cargos vacantes de canónigos en la ciudad de La Serena y se suprimieron los pagos que el gobierno hacía a todos los seminarios del país. ${ }^{114}$ Sumado a lo anterior, y por iniciativa del Presidente Santa María, comenzaba la discusión de la mal llamada reforma teológica:

...Algunas de estas reformas iniciadas desde tiempo atrás, puede en corto tiempo convertirse en ley, puesto que cuenta con la sanción de una de las ramas del poder legislativo. Aludo como lo comprenderéis, al proyecto de ley de secularización de los cementerios...

...esperando que el alto y sereno criterio de los congresales, pueda llevarlas a cabo de una manera tan sabia y tan sobrenatural que, atacando la Iglesia, no perturbe las conciencias $y$, teniendo que resolver todas las leyes fundadas en la religión católica siga Chile su camino político como si en él no hubiera ni una sola piedra en que tropezar... ${ }^{115}$

Las palabras del Presidente resonaban en los oídos de los fieles católicos de La Serena, que, alarmados, expresaban ante la sucesión de los acontecimientos:

...el pueblo no quiere un gobierno ateo, ni un cementerio común para cristianos o no y una ley de matrimonio que siembre la inmoralidad...

Santa María pretende progresar con la libertad de conciencia que es un retroceso pues constituye una desgracia social... Santa María lleva al país a un error y abismo. ${ }^{116}$

Prontamente, la ofensiva liberal empezó a discutir el proyecto de secularización de los cementerios del país, que hasta entonces eran casi todos católicos, «...con excepción de unos pocos construidos por asociaciones disidentes...». ${ }^{117}$

Para los católicos de La Serena, estas medidas y pretendidas reformas respondían, por una parte, a:

...un sueño de los masones de Valparaíso y poder cremar sus cadáveres como lo hacían los romanos. Lo cual equivale a un retroceso en la civilización... ¿Cuál es el objetivo con quemar los cuerpos? La Iglesia mira con horror la

112 1882. "Carta enviada el 19 de agosto". La Diócesis 19.

113 Para más detalles de la carta del Papa León XIII dirigida a Santa María, vid. 1883. Documentos relativos a la presentación hecha al Vaticano en 1878 por el gobierno de Chile, del preberendo don Francisco Paula Taforó, para ocupar la Sede Vacante de la Arquidiócesis de Santiago: 199 y ss. Valparaíso.

114 ANCH. Archivo del Ministerio de Relaciones Exteriores, Vol. 338. Carta del 9 de octubre de 1886 de Orrego al ministro del Culto, en la que le solicita que se nombren los canónigos para la Catedral y se restablezcan los pagos al Seminario, todo ello suspendido desde 1882. Ver 1882. “Edición del 11 de noviembre". La Diócesis 30.

115 1883. "Discurso de Santa María ante el Congreso". La Diócesis 60.

116 Editorial. Ídem.

117 Cifuentes, Abdón. 1936: 384.Tomo II. 
incineración y proclama desde siempre el entierro y respeto a los cuerpos. ${ }^{118}$

Y, por otra, a la «...intención -de los liberales- de destruir todo aquello que huela a católico....». ${ }^{119}$

A su vez, creían que «...si es aprobado - el proyecto de ley-, verían vulnerado su derecho, pues el cementerio católico sería profanado y perdería su carácter de sagrado sin que los católicos puedan sepultarse en dicho lugar y menos aun con sus ritos...».120

Por lo demás, los católicos estimaron que el proyecto de secularización de cementerios atentaba contra la Constitución, pues en su normativa aseguraba que la religión católica era la oficial del Estado. Por esta razón enviaron una carta firmada por 493 personas al Congreso Nacional solicitando el rechazo del proyecto. ${ }^{121}$

Orrego, por su lado, llamó a defender a la Iglesia de sus perseguidores por medio de la oración. ${ }^{122}$ Sin embargo, y pese a las peticiones y protestas que efectuaron los serenenses, el proyecto fue aprobado. Al Obispo no le quedaba más que pedir a los católicos erigir nuevos cementerios, pues los ya existentes quedaban execrados; esto es, sin bendición. ${ }^{123}$ No obstante, Orrego ignoraba que el gobierno había derogado un decreto de 1872, en virtud del cual se podían construir libremente cementerios particulares. Se produjo, a juicio de los católicos, un «nuevo acto despótico y tiránico» ${ }^{124}$ de la autoridad, quedando obligados a enterrar a sus deudos en cementerios execrados, cuestión que implicaba un ataque frontal contra el culto católico. Es más, consideraban que:

.... Los chilenos quedan en peor situación que cualquier secta extranjera que tuviese cementerio particular, pues los individuos de ésta pueden ser sepultados con las ceremonias y ritos de su religión y no están obligados a admitir en sus cementerios los cadáveres de aquellas personas que no fueren de su secta... ${ }^{125}$

Como un efecto de la ofensiva del gobierno, las autoridades civiles de la provincia clausuraron por la fuerza los cementerios parroquiales de Coquimbo, Huasco y otras ciudades que habían sido construidos con fondos de la Iglesia y de los fieles. Frente a tales acontecimientos, los habitantes de la ciudad de La Serena protestaron señalando que "... atacando la religión, atacan de lleno la sociedad, minando sus más sólidos fundamentos con la ley de cementerios se nos ha quitado una preciosa libertad....". ${ }^{126}$ Luego se unieron a las protestas los católicos de Coquimbo, Copiapó, Elqui y de las demás ciudades de la provincia.

La protesta católica se manifestó en diversas cartas y editoriales del periódico «La Diócesis», de las cuales se deduce

118 1882. "Razones para los cementerios laicos". La Diócesis 19

119 1883. La Diócesis.

120 1883. "Editorial". La Diócesis 61.

121 1883. "Carta 23 de junio". La Diócesis 61.

122 1883. "Circular publicada el 14 de julio". La Diócesis

123 1883. "Decreto del obispado de La Serena, publicado el 11 de agosto". La Diócesis 71. Vid. Boletín eclesiástico XXXV: 114 y ss.

124 1883. "Editorial del 18 de agosto". La Diócesis 73.

125 Ídem.

126 1883. "Editorial Primera Protesta de La Serena del 6 de octubre". La Diócesis 86 que para los serenenses la nueva ley era inconstitucional. Recordemos que la Constitución no sólo consagraba que la religión del Estado era la católica, sino que, a su vez, garantizaba el culto de los católicos y el derecho de propiedad. ${ }^{127}$ Pues bien, por efecto de la ley laica, los cementerios que eran de propiedad de la Iglesia o de las parroquias pasaban al Estado. En pocas palabras, se despojaba a los católicos de la propiedad de los recintos, sin previa resolución judicial y expropiación legal, según contemplaba el ordenamiento jurídico. ${ }^{128}$

Asimismo, la Constitución garantizaba la libertad del culto católico. Pues bien, la inhumación de los muertos era, para la Iglesia, un acto propio de su culto. Con la nueva ley, se atropellaba la garantía constitucional, pues el catolicismo quedaba impedido de poder llevar adelante sus ritos y, aun más, se les imponía a sus fieles el aceptar en los cementerios católicos a personas que profesaban otra fe o renegaban del cristianismo.

Sin perjuicio de lo anterior, creemos que las vehementes protestas de los católicos ante la dictación de la ley de cementerios tuvieron un sentido más profundo, propio de sus conciencias católicas. Esto es, que al no contar con lugares sagrados para enterrar a sus deudos, se ponía en jaque la salvación y la vida eterna, cuestión fundamental para los creyentes.

\section{LEY DE MATRIMONIO CIVIL}

A su vez, se tramitaba en el Congreso la ley de matrimonio civil, cuya normativa estaba tomada, en buena parte, de las leyes de la Iglesia. Sin embargo, se la criticaba porque su definición de matrimonio era

...fruto del liberalismo, porque debiendo dar una definición satisfactoria de la materia, no es más que un atropello descarado a nuestra institución, por medio de la cual se sienta como un hecho la libertad de cultos, que aun no existe en Chile católico... ${ }^{129}$

La norma en cuestión señaló requisitos para los futuros contrayentes, pero excluyó exigencias de carácter religioso. Asimismo, trató al matrimonio como un «acto civil», lo vació de su valor de sacramento y agregó que solamente aquel que se celebraba bajo la ley producía efectos legales. Como consecuencia, el matrimonio católico quedaba privado de valor legal y reducido a un contrato privado.

En los impedimentos y prohibiciones, se suprimieron los canónicos, «...los que tienen una relación directa con la religión católica y con la decencia...» Sumado a ello, se estimó

\footnotetext{
127 1833. Constitución Política de Chile. Cap. V. Art. 12, N ${ }^{\circ} 5$. Derecho público de Chile.

128 Ley de expropiación en Campos Harriet Fernando. 1983: 396. La pregunta lógica que nos hacemos es: ¿Cómo fue posible que el gobierno promulgara una ley contraria a las garantías constitucionales y legales? Santa María, con el fin de evitar que la ley fuera tildada de inconstitucional, señaló como fundamento que estaba en peligro la seguridad interior y exterior de la República. Hábil forma de resolver el asunto; sin embargo, ¿en qué sentido estaba en peligro la seguridad del país?

129 1883. "Edición del 9 de junio". La Diócesis 59.
} 
«tiránico e indigno» que el proyecto contemplara títulos de nulidad y divorcio, siendo que eran materias eclesiásticas. ${ }^{130}$

Por otro lado, los católicos criticaban los trámites preliminares al matrimonio que contemplaba la ley, puesto que para poder cumplirlos se debían crear los registros civiles a cargo de funcionarios estatales, excluyendo a la Iglesia, que históricamente había cumplido dichas funciones.

Grandes protestas efectuaron los católicos en la diócesis de La Serena contra las leyes que pretendían secularizar la sociedad. Llegaron a juntar doce mil firmas que en definitiva reprobaban al gobierno liberal.

Mientras se tramitaba la ley, los obispos de las diócesis del país dieron a conocer una Pastoral Colectiva que decía que:

El gobierno no podía legislar sobre esta materia, porque es dogma de fe que el matrimonio como sacramento instituido por... Jesucristo, no puede caer bajo jurisdicción civil... El matrimonio, no es otra cosa que el concubinato, elevado por el Estado a alto prez y a la dignidad de sacramento cristiano. ${ }^{131}$

El clero serenense, por su parte, incitaba a seguir protestando contra el tiránico gobierno de Santa María, y monseñor Orrego llamaba a defenderse por medio de la oración. El clima no podía ser más caótico, y constantes disturbios se producían en La Serena. ${ }^{132}$

Paralelamente, los serenenses, a imitación de los santiaguinos, fundaron la Unión Católica, que tenía por objeto otorgar medios eficaces para «salvar a la sociedad chilena de las grandes desgracias con que amenaza la administración actual...». ${ }^{133}$ Contaron, para ello, con el apoyo de su prelado. Sin embargo, el Congreso aprobó la ley de matrimonio civil. Para los serenenses ello constituyó una humillación hacia el catolicismo, puesto que «...esta ley va a alterar todo: vida, costumbres, moralidad, la conciencia...». ${ }^{134}$

Y evaluaron la labor parlamentaria de ese período con:

... profunda pena... que lo único que ha merecido llamar la atención al país, no por sus bendiciones sino por sus desastres, es la persecución religiosa de que se han hecho viles y abyectos instrumentos, para cumplir los compromisos... que contrajeron con su elector el presidente Santa María. ${ }^{135}$

Seguidamente, el 16 de julio de 1884 Santa María logró la aprobación de la ley de Registro Civil, que llevaría en adelante los registros de nacimiento, matrimonio y defunción de los chilenos, con independencia de las parroquias. Con

130 1883. "Edición del 15 de agosto". La Diócesis 72.

131 Orrego, José Manuel, Larraín Gandarillas Joaquín, Benigno Cruz Domingo. 1883. Pastoral Colectiva sobre el matrimonio. Concepción: Libertad Católica.

132 1883. "Protestas en ediciones del 3 de octubre". La Diócesis 85 у 103.

133 1884. "Edición del 24 de mayo". La Diócesis 129. En cuanto a la Unión Católica, fue fundada por Abdón Cifuentes, patrocinada por don Joaquín Larraín Gandarillas, luego de la dictación de la ley de cementerios laicos. En cuanto a sus estatutos y principios, vid. Boletín Eclesiástico XXXV. 1887: 432 y ss.; Cifuentes Abdón. 1936: 183 y ss. Tomo II; Vergara Rodolfo. 1914: 237 y ss.

134 1884. "Editorial del 12 de enero". La Diócesis 110

135 1884. "Editorial del 26 de enero". La Diócesis 112. ello, el Estado quedaba a cargo de la constitución de las familias, sin interferencia de la Iglesia.

No obstante, la aplicación de la ley de matrimonio encontró resistencia entre los católicos. Según el Presidente Santa María «...por algunas dificultades suscitadas por un calculado y mal entendido espíritu religioso». Sin embargo, para los católicos serenenses la rebeldía a cumplir con la ley obedecía a que «...para los cristianos no hay ni puede haber matrimonio que no sea a la vez un sacramento». ${ }^{136}$

Asimismo, los católicos solicitaban que

... debe de reconocerse la valides del matrimonio celebrado en conformidad a las leyes y ritos que obedecen los creyentes, aunque se exigiere además, para que el matrimonio produjera efectos civiles, que este se registre en el competente registro. De esta manera no se violarían los derechos de nadie... los católicos no se verían obligados a presenciar un acto para ellos evidentemente nulo... ${ }^{137}$

Pero dicha solicitud no fue escuchada, porque significaba mantener la legislación que hasta esos momentos regía en Chile. ${ }^{138}$

Pese a todos los esfuerzos desplegados por evitar la secularización de la sociedad, era un hecho cierto que regían las leyes laicas y, como tales, debían ser cumplidas por los ciudadanos. Era un deber.

\section{LA CiRCular de Agosto de 1885 de Monseñor ORREgo}

Luego de haber revisado algunos capítulos de la vida y pensamiento del obispo Orrego en relación con la tendencia liberal, lógico es pensar y sostener que una vez que entró a regir la ley de matrimonio civil, el prelado «llamó a sus fieles a resistirla», al igual que el clero de las demás diócesis del país. Sin embargo, el prelado emitió una circular donde señalaba:

Después de haberos desposado en la Iglesia andad sin demora o lo más pronto que podais, a la oficina del Registro Civil, porque también es este vuestro deber. Un buen católico debe tener por norma de su conducta obedecer todas las leyes de su Iglesia. ${ }^{139}$

La primera reacción que se tiene al leer el párrafo transcrito es de sorpresa. Desde luego no es la conducta que se esperaría de un hombre que desde muy joven lidió con los gobiernos liberales y las tendencias secularizadoras de algunos sectores de la élite nacional. Incluso da la impresión de que el prelado, por medio de la circular, habría cedido a las mencionadas tendencias. De hecho, para algunos, la pastoral fue un "desencanto» y para otros un "escándalo». El clero del país, y especialmente monseñor Larraín

136 1885. "Editorial 8 de junio". La Diócesis 192.

137 1885. "Editorial de 10 de junio". La Diócesis 193.

138 El Código Civil chileno en su artículo 102 señalaba, al tiempo de la reforma, que «Toca a la autoridad eclesiástica decidir sobre la validez del matrimonio que se trata de contraer o se ha contraído. La ley civil reconoce como impedimento los que han sido declarados tales por la Iglesia Católica. Toca a la autoridad eclesiástica decidir sobre su existencia y conocer dispensa de ellos». Santiago, 1889.

139 1885. "Circular en edición del 21 de agosto" La Diócesis 224; Ramírez Juan Ramón. 1911: 320 y ss. 
Gandarillas, procuraron por todos los medios que tenían a su alcance la no publicación de la circular en Santiago y Valparaíso, con el fin de evitar mayores dificultades de las que ya tenían. ${ }^{140}$

Muy posiblemente, para el clero batallador, la circular de Orrego debió significar una aceptación tácita del ideario del Presidente Santa María, constituyendo, además, una contradicción con los principios e ideas que durante tanto tiempo habían defendido los sacerdotes ultramontanos.

Cabe preguntarnos, entonces, por qué Orrego llegó a tales conclusiones y si se alejó en realidad de la postura católica. Lograr establecer las razones y motivaciones del prelado ha sido un asunto no menos dificultoso, toda vez que nuestra principal fuente en estudio, el periódico "La Diócesis», lamentablemente se encuentra incompleto, cuestión que por lo demás implica un desafío metodológico. Así, desconocemos por qué el Obispo llegó a tales conclusiones y cuáles fueron las reacciones de los católicos de La Serena ante la circular. ${ }^{141}$

En cuanto a los periódicos de Santiago y Valparaíso, sabemos que en ellos nada se publicó, puesto que el clero hizo cuanto pudo por no dar a conocer la postura del prelado.

Por su parte, la historiografía nacional, en general, sepultó en un manto de silencio la opinión del obispo.

Por nuestra parte, estimamos que Orrego no contradijo la doctrina católica ni menos aún se encarriló en el tren de la modernidad. Al contrario, creemos que fue muy consecuente con sus ideas.

Fundamos esta apreciación en el hecho de que el prelado, al dar a conocer su opinión, inició la exposición recordando a los fieles de su diócesis la «verdadera e infalible» doctrina de la Iglesia acerca del matrimonio: «En primer lugar, debéis creer firmemente... que el matrimonio es un verdadero sacramento instituido por Nuestro Señor Jesucristo...». Y agrega más adelante: «El que dijese que el matrimonio civil registrado es un verdadero matrimonio y que basta para constituir a dos personas verdadero marido y mujer diría una cosa contraria a la doctrina católica....». ${ }^{142}$

Claramente, el obispo no se alejó de la doctrina de la Iglesia y del pensamiento católico. Reiteró a sus fieles que el matrimonio era un sacramento y que sólo por él se podía estimar casados a un hombre y una mujer.

Por otro lado, recordemos que, además de ser teólogo, monseñor Orrego era jurista. Más aún, señalamos al principio de esta investigación, que fue un alumno aventajado en la cátedra de derecho canónico y que luego fue profesor de la misma en el Seminario. A su vez, no olvidemos la defensa que presentó ante el ministro Vergara cuando éste le impidió salir del país; o la "reserva de derechos» que efectuó al prestar juramento de su investidura. Todo ello induce a aseverar que tuvo un perfecto conocimiento del derecho nacional y del eclesiástico.

140 Ramírez, Juan Ramón. 1911: 320.; Encina Francisco. 1983-1984: 130. Tomo XXXIV; Silva Cotapos Carlos. 1925: 330.

${ }^{141}$ En la colección original faltan ejemplares y algunas páginas. También existen páginas mutiladas o con otros defectos, que son irreparables.

142 1885. "Circular en edición del 21 de agosto". La Diócesis 224; en Ramírez Juan Ramón. 1911: 320 y ss.
Pues bien, en un primer momento Orrego condenó el proyecto de ley civil, a través de la Carta Pastoral Colectiva, y rechazó la ley de Registro Civil. ${ }^{143}$ Pero, probablemente, siendo la ley una realidad, transcurrido el tiempo y tras analizar detenidamente la ley de matrimonio civil, debió comprender que se basaba en las leyes de la Iglesia.

Así, y por vía de ejemplo, puesto que no es nuestra intención realizar un estudio comparativo, los actuales impedimentos y prohibiciones para contraer matrimonio fueron tomados del derecho canónico, quedando suprimidos aquellos que tenían estricta relación con la religión (como el impedimento de disparidad de cultos). ${ }^{144}$

Además, Orrego captó que las legislaciones estaban armonizadas. A los fieles católicos les estaba permitido seguir ambas reglamentaciones, sin encontrar conflicto en el cumplimiento de sus deberes. En efecto, la ley señalaba: «Es libre para los contrayentes sujetarse o no a los requisitos y formalidades que prescribe la religión a la que pertenecieren $» .{ }^{145}$

Por otro lado, la ley civil mantuvo los principios que regían las costumbres de los chilenos del siglo XIX; esto es, el matrimonio monogámico, al establecer que «no podrán contraer matrimonio los que se hallaren ligados por vínculo matrimonial no disuelto", ${ }^{146}$ el que solamente se podía terminar por la muerte natural de uno de los cónyuges o por declaración de nulidad. Y, además, conservó el principio de la indisolubilidad del vínculo, puesto que en el capítulo relativo al divorcio señaló claramente que «el divorcio no disuelve el matrimonio, sino que suspende la vida en común de los cónyuges». ${ }^{147}$

En consecuencia, el conflicto de intereses entre católicos y liberales, en cuanto a la ley de matrimonio civil, se reducía a la norma que secularizaba el sacramento del matrimonio, la que decía: «el matrimonio que no se celebre con arreglo a las disposiciones de esta ley, no produce efectos civiles». ${ }^{148}$ Ante ello, el prelado indicó claramente:

..el matrimonio se hace en la Iglesia y mientras no se haya celebrado regularmente ante la iglesia, los esposos aunque hayan ocurrido ya al oficial del Registro Civil, no pueden ser marido y mujer, pues son personas libres como antes... ${ }^{149}$

En otras palabras, el Obispo insistió en el punto de que el único matrimonio válido era el celebrado con arreglo a la ley canónica, puesto que «el matrimonio civil... es tan solo un mero acto civil, que se anota en los libros del Registro Civil para que sepa y conste que queréis ser tenidos por marido y mujer...». ${ }^{150}$

Seguidamente, si el único matrimonio válido en definitiva era el realizado en la Iglesia, qué problemas podía presentar

143 1885. La Diócesis 172.

144 Para más detalles, vid. Hamilton Carlos. 1949. Manual de Derecho Canónico: 236 y ss. Santiago: Jurídica de Chile.

145 Código Civil, Art. 1, inciso 2. 739.

146 Código Civil, Art. 4, №1, 740.

147 Ibídem, Art. 19, 744.

148 Ibídem, 739.

149 1885. "Circular en edición del 21 de agosto". La Diócesis 224. Ramírez Juan Ramón. 1911: 320 y ss.

150 Ídem. 
que luego se lo inscribiera en el Registro Civil y así «...podáis gozar de los derechos acordados al efecto por la ley». ${ }^{151}$

Lo anterior es tal vez el argumento de mayor peso que se puede deducir de las palabras de Orrego. Hasta hoy, el matrimonio civil es el fundamento para el orden de sucesión por causa de muerte, la causa de los derechos y deberes entre padres e hijos, el origen de los deberes conyugales, entre otros.

Orrego debió saber cuáles serían las réplicas de su circular. Pero una vez más este hombre tenaz y valiente actuó conforme a su conciencia y a la ley de su amada Iglesia. Seguramente meditó por largas horas qué postura tomar frente a una legislación que era ya una realidad en Chile. No debió ser tarea fácil. Pero una vez que estudió y analizó la situación, tomó la decisión que estimó correcta.

Esta decisión, por lo demás, se vio confirmada en 1919 por la Circular Colectiva del Episcopado chileno sobre la obligación grave de inscribir los matrimonios en el Registro Civil. En ella se lee: «Declaramos que todos los fieles están gravemente obligados a inscribir el propio matrimonio en el Registro Civil... (no en virtud de la ley civil sino por expresa ley eclesiástica particular)». ${ }^{152}$

Probablemente, el clero y los católicos no comprendieron la postura de Orrego, aunque como señala Carlos Silva, «...la experiencia demostró muy pronto que el obispo de La Serena había visto más claro que el clero de Santiago». ${ }^{153}$

\section{EpíLOgo}

Orrego, viejo y enfermo, durante varios años manifestó ante la Santa Sede y el gobierno chileno su deseo de renunciar a su autoridad episcopal. Así, el 4 de noviembre de 1887 el Presidente Balmaceda le comunicaba que el Vaticano había aceptado su renuncia. ${ }^{154}$

Libre ya de su carga, se retiró a Quillota, ciudad donde había transcurrido su niñez. Pero ello no impidió que desde lejos siguiera velando por su diócesis. A los tiempos convulsionados que vivía La Serena por los conflictos entre liberales y católicos, se sumaba la marea protestante, encabezada por Canut de Bon. Ante ello, una vez más el ya anciano obispo entró a batallar dirigiendo a sus viejos feligreses una Pastoral. En ella llamaba a los serenenses a contrarrestar el error religioso y a protestar ante el gobierno por concederle personalidad jurídica a los evangélicos. ${ }^{155}$

Por otro lado, el proyecto de separación entre la Iglesia y el Estado quedó paralizado, porque Santa María tuvo la íntima convicción de que aquél sería perturbador para la paz y el orden social; incluso creyó que, de llevarse a cabo, se podría provocar una revolución. ${ }^{156}$

Monseñor Orrego, luego de una larga vida, murió el 19 de julio de 1891. El Presidente Balmaceda, quien había

\footnotetext{
151 ídem.

152 Para más detalles vid. Hamilton Carlos. 1949: 259.

153 Silva Cotapos Carlos. 1925: 330.

154 ANCH. Archivo del Ministerio de Relaciones Exteriores. Vol. 338

155 Orrego, José Manuel. 1890. Carta pastoral que dirige a sus antiguos diocesanos i amigos el obispo Dimisionario de la Serena. Santiago: Imprenta de la Época.

156 Encina, Francisco. 1983- 1984: 178.Tomo XVIII.
}

sido su alumno en el Seminario de Santiago, homenajeó su memoria ordenando que por cuenta del Estado se embalsamara su cadáver y se hiciesen solemnes honras fúnebres en la Catedral de Santiago.

En 1912, el obispo de La Serena, monseñor Ramón Ángel Jara, entregó a Manuel Guerrero la misión de ir a Santiago para exhumar el cadáver de monseñor Orrego, con el fin de que sus restos reposaran en su propia iglesia Catedral. Trasladado su cuerpo, se celebraban solemnes exequias con asistencia de numeroso clero e innumerables fieles.

\section{ALGUNAS CONCLUSIONES}

La larga pugna entre católicos y liberales en la ciudad de La Serena culminó con una confrontación abierta entre aquéllos y el gobierno del Presidente Domingo Santa María en el último cuarto del siglo xIx. En esa época, a monseñor Orrego se le impidió viajar y se dictaron las reformas teológicas como parte de la venganza del gobierno ante el rechazo de la Santa Sede de la designación como arzobispo de Santiago de Francisco de Paula Taforó, y como parte del programa secularizador de los liberales reformistas.

En ese momento los católicos debieron comprender que las potestades civil y espiritual no podían seguir unidas, y que la separación era inevitable. El catolicismo ultramontano no podía pretender mantener una serie de privilegios en un mundo que cambiaba vertiginosamente.

No eran ya los tiempos en que la Iglesia mantenía su esfera de influencia a través de los gobiernos; por el contrario, en las nuevas circunstancias ella se vio obligada a crear colegios y asociaciones católicas para conservar su hegemonía.

Observando las nuevas tendencias, monseñor Orrego, pastor de los serenenses en el período en que las relaciones entre la Iglesia y el Estado vivieron tal vez el momento más crítico de la historia de Chile, comprendió que era necesario refortalecerse y utilizar las mismas "armas del enemigo» para conservar el dominio sobre las conciencias.

Al iniciar su batalla, contribuyó a dibujar la nueva realidad de la sociedad de La Serena, toda vez que, contrario a lo que pudiese pensarse, fue la disputa entre liberales y católicos lo que en parte determinó las características de los serenenses.

Por efecto de los diversos incidentes en que se vio envuelto Orrego, los católicos serenenses se unieron y batallaron como una asociación con intereses comunes, demostrando lealtad a su obispo y a la doctrina de la Iglesia.

Pese a ello, soplaban en La Serena y en Chile vientos que provenían de la modernidad; con grave perjuicio para los creyentes, se secularizaban los cementerios y el sacramento del matrimonio.

El liberalismo, movimiento entonces considerado por la Iglesia como el mal del siglo, pero específicamente la prohibición de salida del país a Orrego, obligaron a los serenenses a organizarse para conservar sus tradiciones y los valores de su sociedad. Esta organización, que se manifestó en los tiempos más críticos del conflicto, se mantuvo en el tiempo transformándose y readecuándose a los diferentes intereses que se sucedieron. 
En otras palabras, es posible aseverar que como consecuencia de los incidentes ocurridos durante el gobierno de Santa María, los católicos se vieron forzados a defenderse. Esta situación los llevó a organizarse y de paso a bregar por sus tradiciones en el nuevo mundo al que ingresaban.

Con todo, monseñor Orrego, que por más de treinta años luchó contra el liberalismo y los diversos gobiernos de tal tendencia ideológica, fue un obispo no sólo sensato sino que visionario. En efecto, después de una larga trayectoria de defensa a la Iglesia y sus valores, frente a los cambios y reformas secularizantes de carácter inexorable, como la Ley de Matrimonio Civil, optó por una postura que le trajo una serie de recriminaciones por parte del clero nacional ultramontano, que se tradujo básicamente en establecer un pacto de silencio y olvido a lo que este obispo de provincia logró ver mejor que todos sus contemporáneos y, que sólo varias décadas después la Iglesia chilena se allanaría: permitir que los chilenos no sólo cumplieran como buenos católicos al contraer el sacramento del matrimonio, sino que también, el contrato civil para así ser considerados buenos ciudadanos que acatan las leyes del Estado.

Así, el debate político e ideológico enriqueció a la sociedad de La Serena, fortaleció a su clero y, por qué no decirlo, afianzó la figura de Orrego. El obispo, a través de la circular de 1885 , sentó finalmente las bases de la nueva doctrina de la Iglesia frente al liberalismo.

\section{BiBLIOGRAFÍA Y FUENTES}

\section{Fuentes:}

1883. Documentos relativos a la presentación hecha al Vaticano en 1878 por el gobierno de Chile, del preberendo don Francisco Paula Taforó, para ocupar la Sede Vacante de la Arquidiócesis de Santiago. Valparaíso.

ANCH, Archivo del Ministerio de Relaciones Exteriores. Ministerios de Justicia, Culto e Instrucción Pública, Correspondencia. Vol. 227 y 338.

Boletín Eclesiástico XXXV. 1885-1887. Santiago: Imprenta del Correo.

Código Civil de la República de Chile. 1889. Santiago: Imprenta Nacional.

El Correo de la Serena. 1854- 1882. La Serena: Imprenta del Correo de La Serena.

La Diócesis. 1882-1887. La Serena: Imprenta de La Serena.

1878-18887. Sesiones ordinarias de la Cámara de Diputados. Santiago. Id. Sesiones Extraordinarias.

\section{Bibliografía:}

Araneda, Fidel. 1986. Historia de la Iglesia en Chile. Santiago: Paulinas.

Barrios Valdés, Marciano. 1992. Chile y su Iglesia, una sola historia. Santiago: Salesiana.

Bilbao, Francisco. 1995. "Iniciativa de la América. Idea de un Congreso Federal de la República”, en Leopoldo Zea (coord.), Fuentes de la Cultura Latinoamericana. México: Tierra Firme.

Campos Harriet, Fernando. 1983. Historia Constitucional Chilena: las instituciones políticas y sociales. Santiago: Jurídica de Chile.

Chartier, Roger. 2003. Espacio público, crítica y desacralización en el siglo xVIII. Los orígenes culturales de la Revolución Francesa. Barcelona: Gedisa.

Cifuentes, Abdón. 1936. Memorias. Santiago: Nascimiento.

Edwards, Alberto. 2001. La Fronda Aristocrática. Santiago: Universitaria.

Encina, Francisco. 1983-1984. Historia de Chile: Tomo XXXIV. Santiago: Ercilla.

Errázuriz, Crescente: 1934. Algo de lo que he visto. Santiago: Nascimiento.

Eyzaguirre, Jaime. 1995. Historia de las instituciones políticas y sociales de Chile. Santiago: Universitaria.

Góngora, Mario, 1957. Estudios sobre el galicanismo y la ilustración católica en América española. En Apartado de la Revista chilena de historia y Geografía, N 125.

González, Juan Ignacio. 1994. Iglesia y Fuerzas Armadas. Santiago: Universidad de Los Andes.

Guerrero, Manuel. 1934. Crónicas del Seminario y Obispado de la Serena. La Serena: Moderna.

Habermas, Jurgen. 1991. Historia y crítica de la opinión pública. La transformación estructural de la vida pública. Barcelona: Gedisa.

Habermas, Jurgen. 1986. L' espace public: archéologie de la publicité comme dimensión constitutive de la societé bourgeoise. Paris: Payot.

Hamilton, Carlos. 1949. Manual de Derecho Canónico. Santiago: Jurídica de Chile.

Krebs, Ricardo, 1960. El 'pensamiento histórico, políticoy económico del Conde campomanes. Santiago. Ed. De la universidad de Chile

Krebs, Ricardo. 1981. "La Iglesia y el mundo moderno", en Ricardo Krebs (dir.), El pensamiento de la Iglesia frente a la laicización del Estado de Chile 1875-1885. Santiago: Nueva Universitaria.

Larraín, Jorge. 2005. ¿América Latina Moderna? Globalización e identidad. Santiago: LOM Ediciones.

Orlandis, José. 1998. Breve Historia del Cristianismo. Santiago: Universitaria.

Orrego, José Manuel, Larraín Gandarillas Joaquín, Benigno Cruz Domingo. 1883. Pastoral Colectiva sobre el matrimonio. Concepción: Libertad Católica.

Orrego, José Manuel. 1890. Carta pastoral que dirige a sus antiguos diocesanos i amigos el obispo Dimisionario de la Serena. Santiago: Imprenta de la Época.

Ramírez, Juan Ramón. 1911. Vida del Ilustre Obispo Chileno Dr. Don José Manuel Orrego y Pizarro. Santiago: Impr. y Enc. Chile.

Santa María, Alfredo. (Sin fecha) De Taforó a Casanova, en la correspondencia particular del presidente Santa María. 
En: Revista Chilena de Historia y geografía, Santiago. Ed. Universitaria. $\mathrm{N}^{\circ} 107-108$ y 109.

Silva Cotapos, Carlos. 1925. Historia eclesiástica de Chile. Santiago: Imprenta San José.

Subercaseaux, Bernardo. 1997. Historia de las ideas y de la cultura en Chile. Santiago: Universitaria.

Valenzuela Valderrama, Héctor. 1963. Manual de Derecho Canónico. Santiago: Universitaria.

Varas, José Matte. 1983. Historia del Vicariato Castrense en Chile. Santiago: Publicaciones Vicariato Castrense.
Vergara, Rodolfo. 1914. Vida del Illmo. Don Joaquín Larraín Gandarillas, Arzobispo titular de Anazarba. Santiago: Universitaria.

Villalobos Sergio, Silva Osvaldo, Silva Fernando, Estellé Patricio. 2001. Historia de Chile. Santiago: Universitaria.

Walker Martínez, Carlos. 1886. La Administración de don Domingo Santa María. Epílogo. El hombre muerto. Santiago: La Libertad Electoral. 